IZA DP No. 7154

Framing Effects in an Employee Savings Scheme:

A Non-Parametric Analysis

Peter Kooreman

Bertrand Melenberg

Henriëtte Prast

Nathanaël Vellekoop

January 2013 


\title{
Framing Effects in an Employee Savings Scheme: A Non-Parametric Analysis
}

\author{
Peter Kooreman \\ Tilburg University \\ and IZA
}

Bertrand Melenberg

Tilburg University

Henriëtte Prast

Tilburg University

\author{
Nathanaël Vellekoop \\ Tilburg University
}
Discussion Paper No. 7154
January 2013

\author{
IZA \\ P.O. Box 7240 \\ 53072 Bonn \\ Germany \\ Phone: +49-228-3894-0 \\ Fax: +49-228-3894-180 \\ E-mail: iza@iza.org
}

\begin{abstract}
Any opinions expressed here are those of the author(s) and not those of IZA. Research published in this series may include views on policy, but the institute itself takes no institutional policy positions. The IZA research network is committed to the IZA Guiding Principles of Research Integrity.

The Institute for the Study of Labor (IZA) in Bonn is a local and virtual international research center and a place of communication between science, politics and business. IZA is an independent nonprofit organization supported by Deutsche Post Foundation. The center is associated with the University of Bonn and offers a stimulating research environment through its international network, workshops and conferences, data service, project support, research visits and doctoral program. IZA engages in (i) original and internationally competitive research in all fields of labor economics, (ii) development of policy concepts, and (iii) dissemination of research results and concepts to the interested public.
\end{abstract}

IZA Discussion Papers often represent preliminary work and are circulated to encourage discussion. Citation of such a paper should account for its provisional character. A revised version may be available directly from the author. 
IZA Discussion Paper No. 7154

January 2013

\section{ABSTRACT}

\section{Framing Effects in an Employee Savings Scheme: A Non-Parametric Analysis}

Studies have found evidence that seemingly irrelevant details of an income component such as its label have an effect on how it is used. Using a data set with more than one million employee-month observations, we investigate the role of functional form assumptions and time aggregation in the analysis of these effects. In most cases we find evidence that marginal propensities to save differ across income components. Our analysis reveals a large degree of heterogeneity in savings behavior within the year.

JEL Classification: D13, D91, G23

Keywords: framing effects, labeling effects, employee savings, nonparametric methods, behavioral economics

Corresponding author:

Peter Kooreman

Tilburg University

Department of Economics

P.O.B. 90153

5000 LE Tilburg

The Netherlands

E-mail: p.kooreman@uvt.nl

\footnotetext{
* We thank seminar participants for helpful comments and Netspar for financial support and help with the acquisition of the data.
} 


\section{Introduction}

A growing literature shows that seemingly unimportant details of the choice setting for which there is no role in standard economic theory can have a large impact on how individuals behave. A widely studied example is the effect of defaults on choice behavior, in particular, in enrollment in pension plans; see, for example, Beshears et al. (2008).

Another seemingly unimportant detail is the label of an income source. Using different terms ${ }^{1}$ authors found evidence for essentially the same phenomenon: the label of an income source has an effect on how it is used. While researched to a lesser extent than defaults, labeling effects are arguably more puzzling. Default effects can often be rationalized by switching or transaction costs, labeling effects cannot.

The empirical work on labeling effects has used different methodological approaches. Early estimates of the "flypaper effect" generally relied on cross-sectional variation in grants received by local governments, taking this variation to be exogenous; cf. Hines and Thaler (1995). Other work has used (natural) experiments as a source of exogenous variation in income sources. For example, Kooreman (2000) used variation in child benefit amounts induced by policy changes to analyze the effect of the income label "child benefit" on household expenditures. He found that in two-parent families the marginal propensity to consume child clothing out of the child benefits is more than ten times as large as that out of other income sources. For adult clothing such an effect is absent. Since the difference in marginal propensities is even larger for single parent households, the effects cannot be explained by differences in preferences for child goods between fathers and mothers.

Card and Ransom (2011) investigate the retirement savings behavior of

\footnotetext{
${ }^{1}$ Mental accounting effect (Thaler, 1992, 1999), flypaper effect (Hines and Thaler, 1995), label(l)ing effect (Kooreman, 2000; Beatty et al., 2011), non-fungibility, or income framing effect (Epley et al. 2006; Card and Ransom (2011).
} 
tenured and tenure-track college professors. Faculty can make tax-deferred contributions to a retirement savings account in addition to their own mandatory contribution and their employer's contribution. Card and Ransom find that if the employer contribution increases by 1 dollar, supplemental savings fall by $\$ 0.30$ dollar. If the mandatory employee contribution increases by $\$ 1$, supplementary savings fall by $\$ 0.70$. These effects are largely identified using cross-section variation between universities and colleges. ${ }^{2}$

Two recent papers have used small-scale field experiments to study (pure) labeling effects. Epley et al. (2006) asked US residents to recall how they had spent the 2001 tax rebate that provided each tax paying American household with a check between $\$ 300$ and $\$ 600$. To remind them of the rebate, participants were made to read one of two randomized descriptions of this policy measure. Participants to whom the rebate was described as "withheld income" reported that they had spent only 25 percent of it, while those to whom the rebate was described as "bonus income" reported to have spent 87 percent. In a related experiment, Harvard undergraduates received $\$ 50$ and were informed that this came from a university fund financed by tuition fees. Some participants were told they were receiving a "tuition rebate", others that they were receiving an "income bonus". After a week, undergraduates who had received the "income bonus" reported having consumed twice as much out of the $\$ 50$ than those who had received the "tuition rebate" (\$22.04 versus $\$ 9.55$ ). Abeler and Marklein (2008) conducted a field experiment in a wine restaurant. People who received a voucher labeled for drinks (worth less than the average amount usually spent on drinks) spent 25 percent more on drinks than those who received a voucher for the entire bill.

\footnotetext{
${ }^{2}$ In general, income components do not only differ in terms of their label, but also in other dimensions, such as timing of payment, visibility to the recipient, and institution from which it is received. Following Card and Ransom (2011), in those cases we will use the term 'framing effects' when marginal propensities to save differ across income components. We will reserve 'labeling effects' for cases in which income components merely differ is terms of their label, all else equal.
} 
The purpose of the present paper is to further strengthen the methodology for measuring framing effects. Previous work was typically based on linear or quadratic parametric specifications, and used annual aggregates of savings, income and expenditures, choices largely guided by the aggregation level of the data and sample sizes. For the present paper we had access to an unusually large data set with information on savings contributions and many different income components for 1.3 million employees-month observations. This allows us to analyze the sensitivity of results to using more flexible, non-parametric functional forms, and to using a finer time grid (monthly versus annually).

We explain monthly inlay in a tax-deferred savings account using nonparametric equations (up to a constant) in total income, with individual fixed effects, estimated separately for each month of the year. For comparison, we also estimate linear, quadratic, and cubic equations in total income, with individual fixed effects, estimated separately for each month of the year; and the same equations imposing that slope coefficients are constant across months. In addition, we estimate models based on annual aggregates of savings and income rather than monthly data. In all of these specifications we then test whether individual income components have any additional explanatory power. In a correctly specified model and in the absence of framing effects this should not be the case.

We focus on the marginal propensity to save into a particular savings account. In general, life cycle models do not imply that marginal propensities to save (mpss) out of different income components into a particular savings account should be equal. For example, different mpss into one savings account could be offset by opposite mpss into other savings accounts. The savings account we consider can only be used to purchase future leisure, through parental leave, taking a sabbatical, or early retirement. In addition, at the time our data apply to it was the only savings account that allowed 
for voluntary tax-deferred saving, and it is unlikely that employees used other savings accounts for the same purpose. Our marginal propensities to save can therefore be interpreted as marginal propensities to purchase future leisure.

We find evidence of framing effects for most specifications, including those with the highest degree of flexibility. Our monthly results indicate a large variation in behavior within the year. These results strengthen and add detail to earlier conclusions that policy makers have effective instruments at their disposal to affect the use of income components at low cost.

The paper proceeds as follows. Section 2 describes the data and provides the necessary institutional background. Section 3 presents the econometric model and our estimation and testing procedure. Section 4 presents the results and section 5 concludes.

\section{$2 \quad$ Data and Institutional Setting}

Two financial firms in the Netherlands provided salary records of all of their employees. One firm is primarily active as a bank (and will be referred to as Bank), while the other firm is primarily active as an insurer (to be referred to as Insurer). For each employee and each month of the years 2005, 2006, and 2007 the data contains information on many different wage components which we aggregate into nine comparable salary components. We also observe deposits into two tax-favored savings schemes (and withdrawals from one). In addition, there is some information on employee characteristics.

In the years the data apply to employees in the Netherlands had three main options regarding tax-favored employee saving. One was to participate in the Life Course Savings Scheme (LCS, Levensloopregeling in Dutch), which was introduced in 2006. A second option was to save in the Employee Savings Scheme (ESS, Spaarloonregeling), another tax-favored savings scheme that had already been in place for several decades. The third 
option was not to participate in either scheme (participation in both schemes at the same time was not permitted). The LCS scheme allowed workers to save up to a maximum of 12 percent of gross annual income, while the maximum contribution in the EES scheme was a mere 600 euro. Therefore, our endogenous variable of main interest is how much to deposit each month in the LCS.

Panel A of table 1 presents the summary statistics for all employees. The participation rate in the LCS was 6-8 percent, which is around the national average. Panel B shows the summary statistics for a subgroup of employees with strictly positive savings in at least one pair of months (January 2006 January 2007). This subsample receives on average a higher salary, is older and has a higher fraction of men.

\section{The econometric model}

Let $s_{i t}$ denote the deposited amount in the LCS in month $t$ by individual $i$ and let $g_{i}$ stand for the group of people to which individual $i$ belongs. To test for framing effects, we shall consider subgroups

$$
I_{g, t, T}=\left\{i \mid s_{i t}>0, \quad s_{i, t-T}>0, \quad g_{i}=g\right\}
$$

Thus, we consider subgroups of individuals that deposited a positive amount in the LCS in month $t$ as well as $T$ months before month $t$ and that belong to group $g$. In our application, $t$ will be each of the months in 2007, $T$ will be 12 months, while $g$ will stand for a group characteristic. In particular, we shall make a distinction between being employed by the Bank and the Insurer. ${ }^{3}$

\footnotetext{
${ }^{3}$ These subgroups are convenient samples for the purpose of the present paper. They are selective, but to establish whether framing effects exist, it suffices to detect them in one subgroup.
} 


\subsection{Nonparametric and parametric functional forms}

We first describe our most general specification. For individuals $i$, belonging to subgroup $I_{g, t, T}$, we postulate

$$
s_{i \tau}=f_{\tau}\left(\sum_{\ell} y_{i \tau}^{\ell}\right)+\zeta_{i \tau}, \quad \zeta_{i \tau}=\eta_{i}+\epsilon_{i \tau}, \quad \tau=t, t-T,
$$

where $y_{i \tau}^{\ell}$ is income component $\ell$ of employee $i$ in month $\tau, f_{\tau}$ is the (group $g$-) specific unknown link function, depending on time $\tau$, and $\zeta_{i \tau}$ is the error term, decomposed in an individual $i$ specific effect $\left(\eta_{i}\right)$ and an individual and time specific idiosyncratic effect $\left(\epsilon_{i \tau}\right)$. Specification (2) is allowed to depend on the group $g$, but for notational convenience, we shall suppress this dependence.

To deal with the individual effect $\eta_{i}$, we take time differences, resulting in

$$
s_{i t}-s_{i, t-T}=f_{t}\left(\sum_{\ell} y_{i t}^{\ell}\right)-f_{t-T}\left(\sum_{\ell} y_{i, t-T}^{\ell}\right)+\left(\epsilon_{i t}-\epsilon_{i, t-T}\right) .
$$

We shall assume

$$
E\left(\epsilon_{i t}-\epsilon_{i, t-T} \mid \sum_{\ell} y_{i t}^{\ell}, \sum_{\ell} y_{i, t-T}^{\ell}\right)=0 .
$$

Given this assumption, the unknown regression functions $f_{t}(\cdot)$ and $f_{t-T}(\cdot)$ of equation (3) can be estimated by applying, for example, Linton and Nielsen's (1995) method while imposing their regularity conditions and additional distributional assumptions. This estimation approach proceeds as follows. First, consider the auxiliary nonparametric regression for $i \in I_{g, t, T}$

$$
s_{i t}-s_{i, t-T}=h\left(\sum_{\ell} y_{i t}^{\ell}, \sum_{\ell} y_{i, t-T}^{\ell}\right)+\epsilon_{i, t, t-T},
$$

with

$$
E\left(\epsilon_{i, t, t-T} \mid \sum_{\ell} y_{i t}^{\ell}, \sum_{\ell} y_{i, t-T}^{\ell}\right)=0
$$


One can estimate $h$ nonparametrically, for instance, using a standard Kernel estimator or a local linear regression approach. Next, consider some distribution $\mathbb{Q}$ over $\sum_{\ell} y_{i, t-T}^{\ell}$. Then taking expectation of $h\left(\sum_{\ell} y_{i t}^{\ell}, \sum_{\ell} y_{i, t-T}^{\ell}\right)$ with respect to $\mathbb{Q}$, keeping $\sum_{\ell} y_{i t}^{\ell}$ fixed, we find

$$
\begin{aligned}
E_{\mathbb{Q}}\left(h\left(\sum_{\ell} y_{i t}^{\ell}, \sum_{\ell} y_{i, t-T}^{\ell}\right)\right) & =f_{t}\left(\sum_{\ell} y_{i t}^{\ell}\right)+E_{\mathbb{Q}}\left(f_{t-T}\left(\sum_{\ell} y_{i, t-T}^{\ell}\right)\right) \\
& =f_{t}\left(\sum_{\ell} y_{i t}^{\ell}\right)+c_{\mathbb{Q}}
\end{aligned}
$$

with $c_{\mathbb{Q}}$ some constant depending on $\mathbb{Q}$. Thus, we can estimate $f_{t}$ nonparametrically up to a constant by calculating $E_{\mathbb{Q}}\left(h\left(\cdot, \sum_{\ell} y_{i, t-T}^{\ell}\right)\right)$, using for $h$ its nonparametric estimator. Similarly, we can estimate $f_{t-T}(\cdot)$ nonparametrically (up to a constant) by using an auxiliary distribution $\mathbb{Q}$ over $\sum_{\ell} y_{i, t}^{\ell}$. Like Linton and Nielsen (1995) we use the empirical distribution functions of $\sum_{\ell} y_{i, t}^{\ell}$ and $\sum_{\ell} y_{i, t-T}^{\ell}$ to form the auxiliary distribution $\mathbb{Q}$.

We shall also consider the parametric specifications

$$
s_{i t}=\beta_{0 t}^{J}+\sum_{j=1}^{J} \beta_{j t}^{J}\left(\sum_{\ell} y_{i t}^{\ell}\right)^{j}+\eta_{i}^{J}+\epsilon_{i t}^{J} .
$$

In our application, we consider $J=1,2,3$. Taking time differences to eliminate the individual effect, we have

$$
s_{i t}-s_{i, t-T}=\delta_{0 t}^{J}+\sum_{j=1}^{J} \beta_{j t}^{J}\left(\sum_{\ell} y_{i t}^{\ell}\right)^{j}-\sum_{j=1}^{J} \beta_{j, t-T}^{J}\left(\sum_{\ell} y_{i, t-T}^{\ell}\right)^{j}+\xi_{i, t, t-T}^{J},
$$

with $\delta_{0 t}^{J}=\beta_{0 t}^{J}-\beta_{0, t-T}^{J}$ and $\xi_{i, t, t-T}^{J}=\epsilon_{i t}^{J}-\epsilon_{i, t-T}^{J}$. Imposing a distributional assumption analogous to (6), we can estimate this equation using standard linear regression techniques.

\subsection{Testing for framing effects}

We can test whether separate income components do play a role or not, by considering as null hypothesis equation (2), with

$$
E\left(\eta_{i}+\epsilon_{i t} \mid \sum_{\ell} y_{i t}^{\ell}, y_{i t}^{1}, \ldots, y_{i t}^{L}\right)=0
$$


We can test this hypothesis by calculating the correlation between the estimated error term $y_{i t}-\widehat{f}_{t}\left(\sum_{\ell} y_{i t}^{\ell}\right)$, and each of the independent variables $y_{i t}^{1}, \cdots, y_{i t}^{L}$, with $\widehat{f}_{t}(\cdot)$ the nonparametric estimate of $f_{t}(\cdot)$, by extending the test statistic like the one proposed by Fan and Li (1996) to the current case.

Testing (10) makes sense in case the individual effect $\eta_{i}$ is assumed to be uncorrelated with the independent variables. In case the individual effect might be correlated with the independent variables, it seems better to consider as null hypothesis equation (5), with

$$
E\left(\epsilon_{i t}-\epsilon_{i, t-T} \mid \sum_{\ell} y_{i t}^{\ell}, \sum_{\ell} y_{i, t-T}^{\ell}, y_{i, t-T}^{1}, \ldots, y_{i, t-T}^{L}, y_{i t}^{1}, \ldots, y_{i t}^{L}\right)=0 .
$$

Again, we can test this hypothesis by calculating now the correlation between the estimated error term

$$
\left(s_{i t}-\widehat{f}_{t}\left(\sum_{\ell} y_{i t}^{\ell}\right)\right)-\left(s_{i, t-T}-\widehat{f}_{t-T}\left(\sum_{\ell} y_{i, t-T}^{\ell}\right)\right),
$$

and each of the independent variables $y_{i t}^{1}, \ldots, y_{i t}^{L}$ and/or $y_{i, t-T}^{1}, \ldots, y_{i, t-T}^{L}$, extending the test statistic like the one by Fan and Li (1996) to this case.

Since this nonparametric test procedure is likely not to be very powerful we follow an alternative approach. First, we search for parametric specifications close to the nonparametric estimates $\widehat{f}_{t}$ and $\widehat{f}_{t-T}$. Then we test (5) combined with (11) using these parametric estimates. Under this null hypothesis we have

$$
E\left(\xi_{i, t, t-T}^{J}\left(\begin{array}{c}
y_{i t}^{\ell} \\
y_{i, t-T}^{\ell}
\end{array}\right)\right)=0
$$

with $\xi_{i, t, t-T}^{J} \equiv \epsilon_{i t}^{J}-\epsilon_{i, t-T}^{J}$, and $y_{i t}^{\ell}$ and $y_{i, t-T}^{\ell}$ are the $\ell$-th income component of individual $i$ at time $t$ and $t-T$, respectively. The test statistic for some couple of time periods $t$ and $t-T$ will therefore be based on

$$
\frac{1}{N} \sum_{i} \widehat{\xi}_{i, t, t-T}^{J}\left(\begin{array}{c}
y_{i t}^{\ell} \\
y_{i, t-T}^{\ell}
\end{array}\right)
$$

where $\widehat{\xi}_{i, t, t-T}^{J}$ denotes the estimated error term, and $N$ is the number of observation in $I_{g, t, T}$. Under the null hypothesis, we can derive the limit 
distribution of (13) (after scaling by $\sqrt{N}$ ) which is a normal distribution with mean vector zero and covariance matrix, say, $V^{J, \ell}$. Our test statistic then becomes

$T^{J, \ell}=N\left(\frac{1}{N} \sum_{i} \widehat{\xi}_{i, t, t-T}^{J}\left(\begin{array}{c}y_{i t}^{\ell} \\ y_{i, t-T}^{\ell}\end{array}\right)\right)^{\prime}\left(\widehat{V}^{J, \ell}\right)^{-1}\left(\frac{1}{N} \sum_{i} \widehat{\xi}_{i, t, t-T}^{J}\left(\begin{array}{c}y_{i t}^{\ell} \\ y_{i, t-T}^{\ell}\end{array}\right)\right)$,

with $\widehat{V}^{J, \ell}$ a consistent estimate of $V^{J, \ell}$. Under the null hypothesis this test statistic follows a $\chi^{2}$-distribution with two degrees of freedom. The test can easily be extended by including higher order (cross) terms (or other transformations) of $y_{i t}^{\ell}$ and $y_{i, t-T}^{\ell}$ in (12). Moreover, the test can easily be extended by combining some or all income components.

As benchmark, we will also estimate

$$
s_{i t}=\beta_{0 t}^{J}+\sum_{j=1}^{J} \beta_{1 j}^{J}\left(\sum_{\ell=1}^{L} y_{i t}^{\ell}\right)^{j}+\sum_{\ell=2}^{L} \beta_{2 \ell}^{J} y_{i t}^{\ell}+\eta_{i}^{J}+\epsilon_{i t}^{J},
$$

and test the hypothesis $H_{0}: \beta_{22}^{J}=\cdots=\beta_{2 L}^{J}=0$ (note that $y_{i t}^{1}$ is excluded from the second summation), using standard panel data techniques. This test is easier to perform than (14), since it allows the use of standard statistical packages. But contrary to (8) equation (15) is more restrictive under the null hypothesis: We assume that the slope parameters do not vary across months. We shall estimate and test (15) for different groups $g$, using the subpanel of observations $i$, with $g_{i}=g$, for whom $s_{i t}>0$ for at least two different months. Just like the test for (12), we can easily extend this benchmark test by including higher order (cross) terms of $y_{i t}^{\ell}$ and cross terms of $y_{i t}^{\ell}$ and $\sum_{\ell} y_{i t}^{\ell}$ in regression (15).

Finally, we will estimate specification (15) and its extensions using annual aggregates instead of the monthly data, and test the corresponding null hypothesis. We shall estimate and test this alternative specification for different groups $g$, using now the subpanel of observations $i$, with $g_{i}=g$, for whom $s_{i t}>0$ for at least one month in each of the two different years. 


\section{Empirical Results}

\subsection{Estimation results}

As a first step we estimate equation (2) for the individuals belonging to $I_{g, t, T}$, with $g$ the group of individuals employed at the Insurer, $t$ the months January to December 2007, and $T=12$ months, using the nonparametric estimation procedure described in the previous section. In the original Linton and Nielsen (1995) estimator, the corresponding confidence band is based on the assumption of homoskedasticity. We follow Vollebergh et al. (2009) by extending the asymptotic limit distribution by also allowing for the possibility of heteroskedasticity. Figures 1 to 12 show the resulting nonparametric estimates, with the corresponding $95 \%$ pointwise confidence bands. Because the level is not identified in this nonparametric estimation, the level per figure is fixed at the mean of the corresponding dependent variable in the year 2006. In the same figures we also present the estimations of the parametric specifications (8) for $J=1,2,3$, using OLS applied to (9). The left panels of each figure shows the outcomes for 2006, the right panels for 2007. The upper panels present the comparison between the nonparametric estimates and the parametric ones for $J=1$, the middle panels show the corresponding outcomes for $J=2$, while the bottom panels show the outcomes for $J=3$. The level of the parametric curves is determined such that this curve equals (or crosses) the corresponding nonparametric curve at the median value of the income variable.

As is clear from these figures, there is a month effect, as the shape of the curves changes over the months. For instance, the shape is clearly decreasing in January, but increasing in February, while the curve has a U-shape in March. In general, one would expect an increasing relationship between the amount saved in the LCS and income. The negative relationship in January might be related to a new year's resolution to save more in the new year, if such a resolution is more prevalent among low income employees. 
In a number of cases, there is also a combination of a year and a month effect, as is illustrated by, for example, the results of February and December: the shape of the nonparametric estimation of February in 2006 is increasing and concave, while in 2007 the shape is increasing and convex. For December, the shape changes from inverted U-shaped in 2006 to U-shaped in 2007. In addition, the graphs show that in most cases at least one (and sometimes more than one) of the parametric specifications $(J=1,2,3)$ fits inside the nonparametric confidence band (possibly after an additional change in the level, deviating from the median level, used to plot the graphs). For these months the class of parametric models seems flexible enough to fit the data sufficiently well. But there are also some clear exceptions, in particular, February, April, and October. For these months, the curvature imposed by the chosen parametric specifications seems to be too specific, preventing a good fit of the data.

\subsection{Test results}

Estimation results for equation (15) are presented in Tables 2 and 3, for the Bank and the Insurer, respectively. The time specific constant $\beta_{0 t}^{J}$ is decomposed into a year and month effects. For brevity, results are only reported for $J=1$. The first column in each table presents the results for all employees; the other columns consider groups by gender, by age being below or above 45 , and by total income being below or above the monthly median. The results do not vary much across groups. Tables 4 and 5 present results for the same specification, but with annual instead of monthly data. We exclude base salary as individual income component (i.e., base salary is $y_{i t}^{\ell}$ in terms of (15)). Moreover, for the group of individuals employed at the Insurer and with income below the median, the income component "bonus" is never positive for the included individuals, and therefore excluded from the regressions. 
The framing test results for equation (15), $J=1$, are found in the bottom rows of tables 2 and 3 (monthly data) and 4 and 5 (annual data). For the Bank equality of the mpss is rejected in all cases. For the Insurer the equality of the mpss is not rejected, except for the group with income below median (annual data, but also almost so for monthly data). For the Bank "holidays allowance" and "LCS contribution" are the income components that most significantly affect savings contributions. For the Insurer, very few individual coefficients are significant. The results using annual and monthly data for equation (15) are qualitatively similar but the magnitudes of the marginal propensities to save differ. This is not surprising given that they are different aggregations of the monthly results displayed in Figures 1 to 12.

In the cases $J=2$ and $J=3$ we also include all higher order terms and cross terms of the individual income components as well as the cross terms of the individual income components and total income up to order $J$. Table 6 summarizes the test results for $J=1,2,3$ (with $J=1$ following from tables 3 and 5). Equality of mpss is rejected in all cases, except for the Insurer in case $J=1$.

Next, we present the outcomes for the nonparametric equation (2) based on test statistic (14). Table 7 reports the test outcomes for the Insurer, for the month couples January 2006/2007 to December 2006/2007, for $J=$ $1,2,3$, for each of the income components separately, and for all income components together. We only present the results when including the first order terms in (12). Including higher order (cross) terms yields similar results. We find that the null hypothesis of no framing effect is systematically rejected at the $5 \%$ significance level for the income component "other income," for the months May up to and including December. For the months May to November rejections are found for all three parametric specifications $(J=1,2,3)$, while for December it only applies to $J=2,3$ (where $J=2$ 
seems to give a fit in line with the nonparametric estimate). Moreover, the null hypothesis of no framing effect is also rejected at the $5 \%$ significance level for the income component "base salary," for the months May, July, September, October, and November $(J=1,2,3)$, and June and August $(J=3)$. The null hypothesis is not rejected for these two income components for the other months, and also not rejected for any of the other income components for the time period under consideration. So, assuming that the employees working at the Insurer form a homogeneous group, the conclusion seems to be that there is a framing effect, in line with the evidence summarized in Table 6, particularly for $J=2,3$.

In Table 8 we present the corresponding outcomes for the Bank. We only find a few rejections of the null hypothesis of no framing effect at the $5 \%$ significance level. For the month July we find a rejection of the null hypothesis for the income component "overtime" $(J=1,2,3)$, and for the month August we find a rejection of the null hypothesis for the income component "bonus" $(J=1,2,3)$. Moreover, for the months July and November we find a rejection of the null hypothesis for the income component "base salary" $(J=3)$. For the simultaneous test, we find clear rejections of the null hypothesis in case of the months August and November.

These results are not fully in line with the results summarized in Table 6 , indicating that the parametric estimation and test results might be driven by misspecification. To investigate whether this is the case, Figures 13-14 compare the parametric and nonparametric estimation results for $g=$ Bank for the months August and November, for which the simultaneous tests reject the null hypothesis. The figures show that in these two months the three parametric specifications have some difficulty to yield an appropriate fit (in line with the nonparametric estimates), with as only exception August for $J=2$, where after some shifting a reasonable fit seems to be possible. But for this case the $p$-value of the simultaneous test is only 0.10 (although 
for the income component "bonus" it equals 0.03). Thus, we cannot exclude the possibility that the rejections of the null hypotheses for the Bank are partly due to misspecification.

In sum, we find evidence for framing effects in most cases, but the type of deviations from the null of equal marginal propensities to save varies across specifications. For example, when the shape of the savings-income relationship is not allowed to vary across months evidence of framing is found more often for the Bank than for the Insurer. The reverse pattern is found when the shape of the savings-income relationship is allowed to vary across months. The former result is likely to be partly driven by misspecification. The latter result is based on a much more flexible specification and therefore more likely to reflect genuine framing effects.

\section{Conclusion}

In this paper we have investigated framing effects in an employee savings scheme, using specifications that differ in functional form flexibility and in the time aggregation of the data. In most cases we find evidence that marginal propensities to save differ across income components.

Our analysis reveals a large degree of heterogeneity in savings behavior within the year. Not only the curvature, but also the sign of the relationship between total income and savings appears to vary across months. While we find the expected positive relationship for 22 out the 24 months our data apply to, the relationship appears to be negative for January 2006 and January 2007.

The strongest evidence for a pure labeling effect is found for employees of the Insurer (Table 7). Even though base salary and other income are paid with identical frequency and timing (monthly) the marginal propensities to save out of these two income components differ for most of the months. This remains undetected when using the more restrictive specifications or 
the annual aggregation of the data.

Employees at the Bank and the Insurer have higher education levels on average than the general population and are likely to be more financially literate. The degree of framing reported here is therefore likely to be a lower bound of the framing effects that would be found in the general population.

The heterogeneity within the year helps to clarify the pathways that lead to framing effects. The atypical result for January suggests that savings contributions do not only depend on the label of an income component and the frequency with which it is paid, but also on the calendar timing of these payments. Thus employers seem to have several low cost instruments for affecting savings rates: changing the labels of income components, changing their relative sizes, changing payment frequencies, and changing the calendar timing of payments. 


\section{References}

Abeler, Johannes and Felix Marklein (2008), Fungibility, Labels and Consumption, IZA discussion paper no. 3500.

Beatty, Timothy K.M., Laura Blow, Thomas F. Crossley, and Cormac O'Dea (2011), Cash by any other Name? Evidence on Labelling from the UK Winter Fuel Payments, IFS Working Paper no. 11/10.

Beshears, John, James J. Choi, David Laibson, and Brigitte C. Madrian (2008), The Importance of Default Options for Retirement Saving Outcomes: Evidence from the United States, in: Stephen J. Kay and Tapen Sinha, editors, Lessons from Pension Reform in the Americas, Oxford: Oxford University Press, 2008, 59-87.

Card, David and Michael Ransom (2011), Pension Plan Characteristics and Framing Effects in Employee Savings Behavior, Review of Economics and Statistics, 93, 228-243.

Epley, Nicholas D. Mak and L. C. Idson (2006), Bonus or Rebate?: The Impact of Income Framing on Spending and Saving. Journal of Behavioral Decision Making, 19, 213-227

Fan, Y. and Q. Li (1996), Consistent Model Specification Tests: Omitted Variables and Semiparametric Functional Forms, Econometrica, 64, 865-890.

Hines, J. and Richard H. Thaler (1995), Anomalies: the flypaper effect, Journal of Economic Perspectives, 9, 217-226.

Kooreman, Peter (2000) The Labeling Effect of a Child Benefit System, American Economic Review, 90, 571-583.

Linton O. and J.P. Nielsen (1995), A Kernel Method of Estimating Structured Nonparametric Regression Based on Marginal Integration, Biometrika, 82, 93-100.

Thaler, Richard H. (1992), Saving and Mental Accounting, in: George Loewenstein and Jon Elster, editors, in Choices over Time, New York: Russell Sage Foundation, 287-330.

Thaler, Richard H. (1999), Mental Accounting Matters, Journal of Behavioral Decision Making, 12, 183-206. 
Vollebergh, Herman R.J., Melenberg, Bertrand., and Dijkgraaf, Elbert. (2009), Identifying Reduced-form Relations with Panel Data: The Case of Pollution and Income, Journal of Environmental Economics and Management, 58, 2742 . 

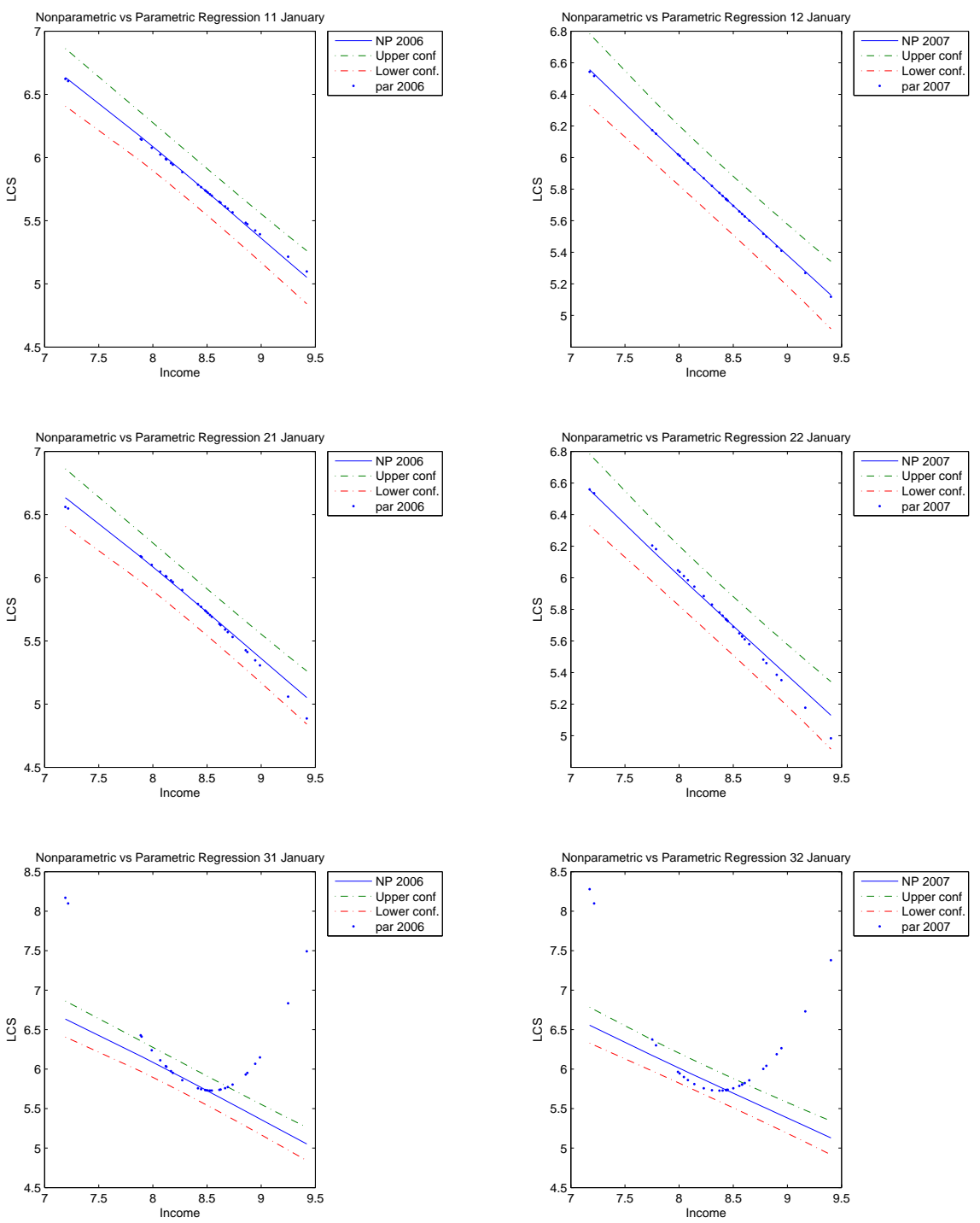

Figure 1: Parametric vs Nonparametric (Insurer): January. 

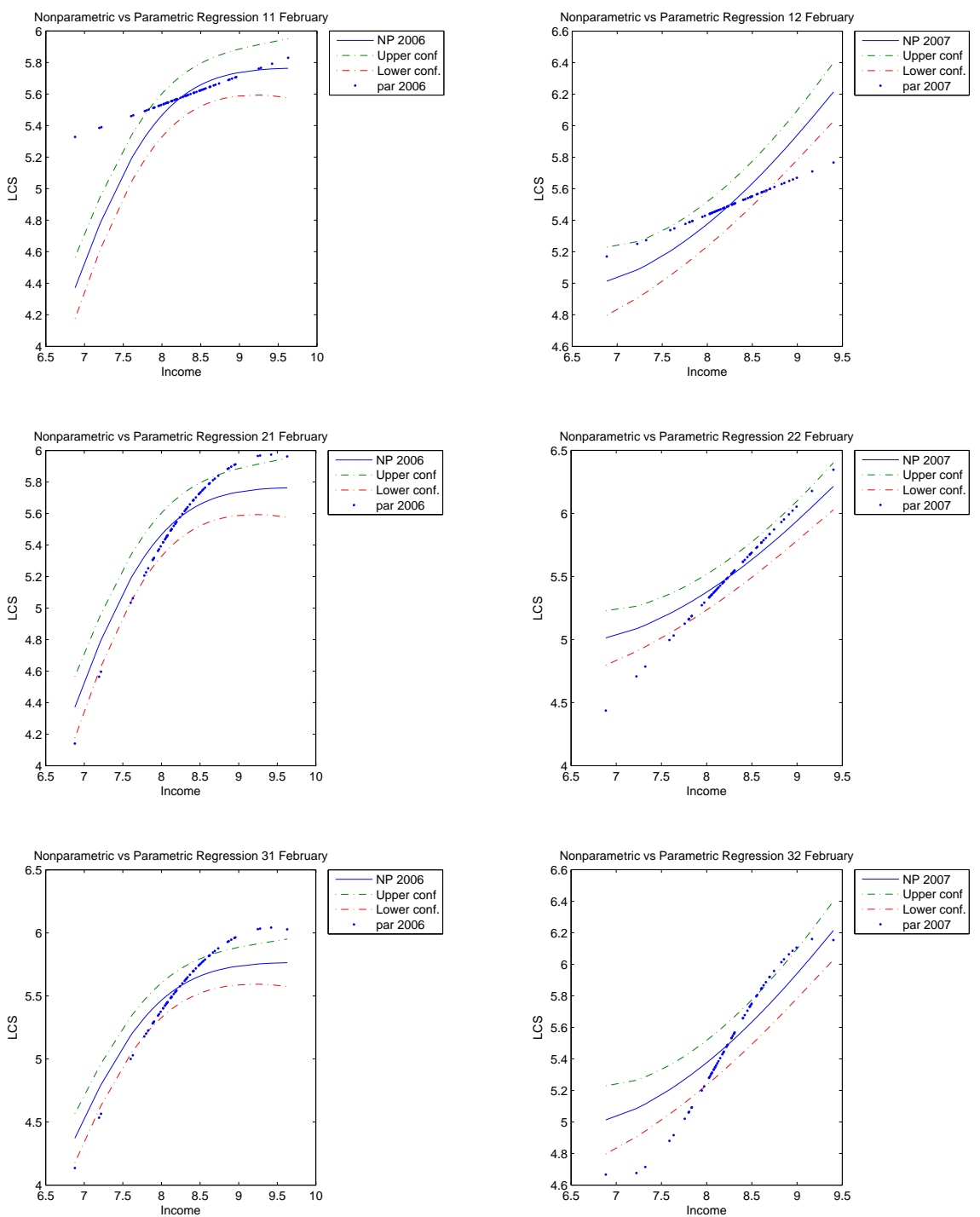

Figure 2: Parametric vs Nonparametric (Insurer): February. 

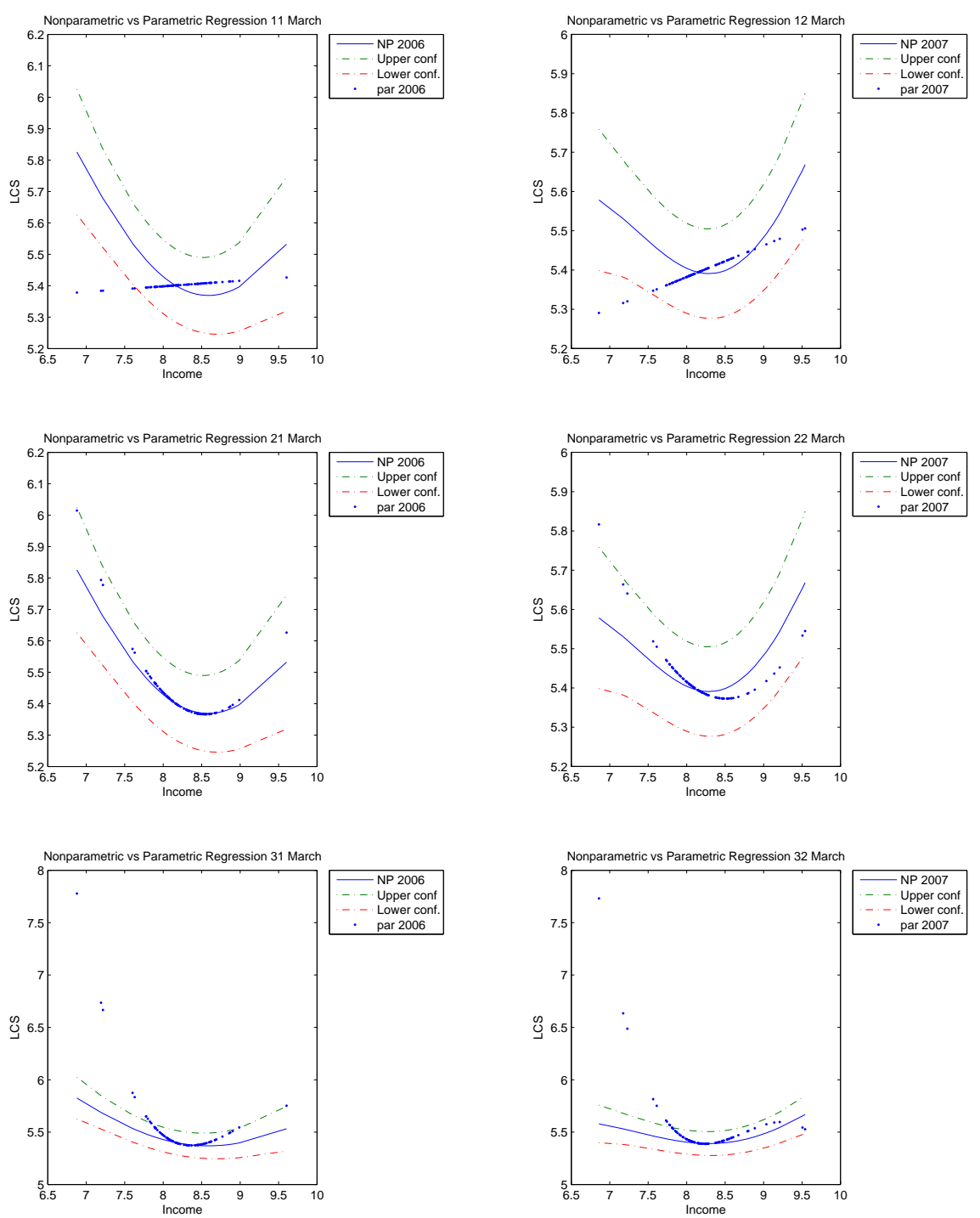

Figure 3: Parametric vs Nonparametric (Insurer): March. 

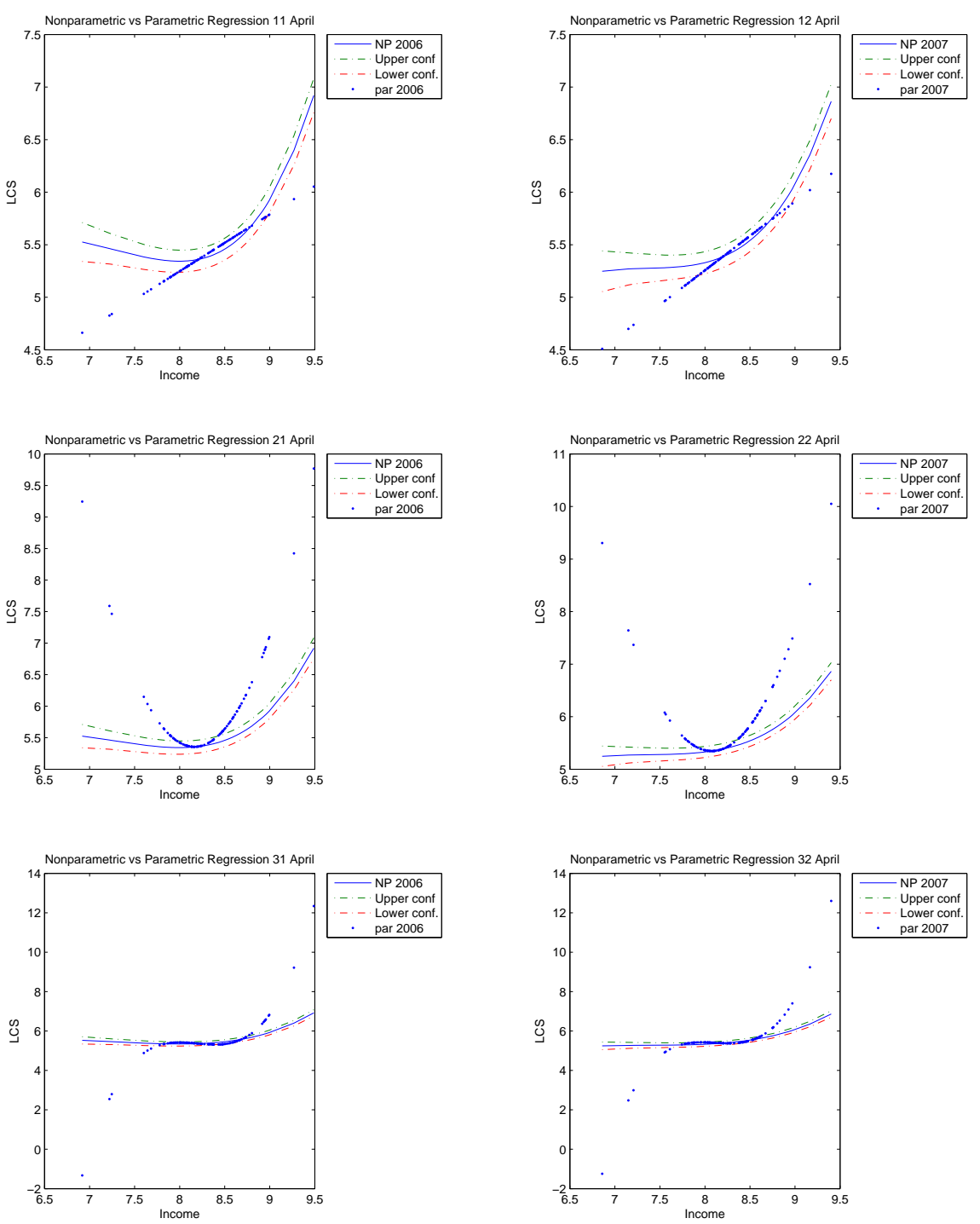

Figure 4: Parametric vs Nonparametric (Insurer): April. 

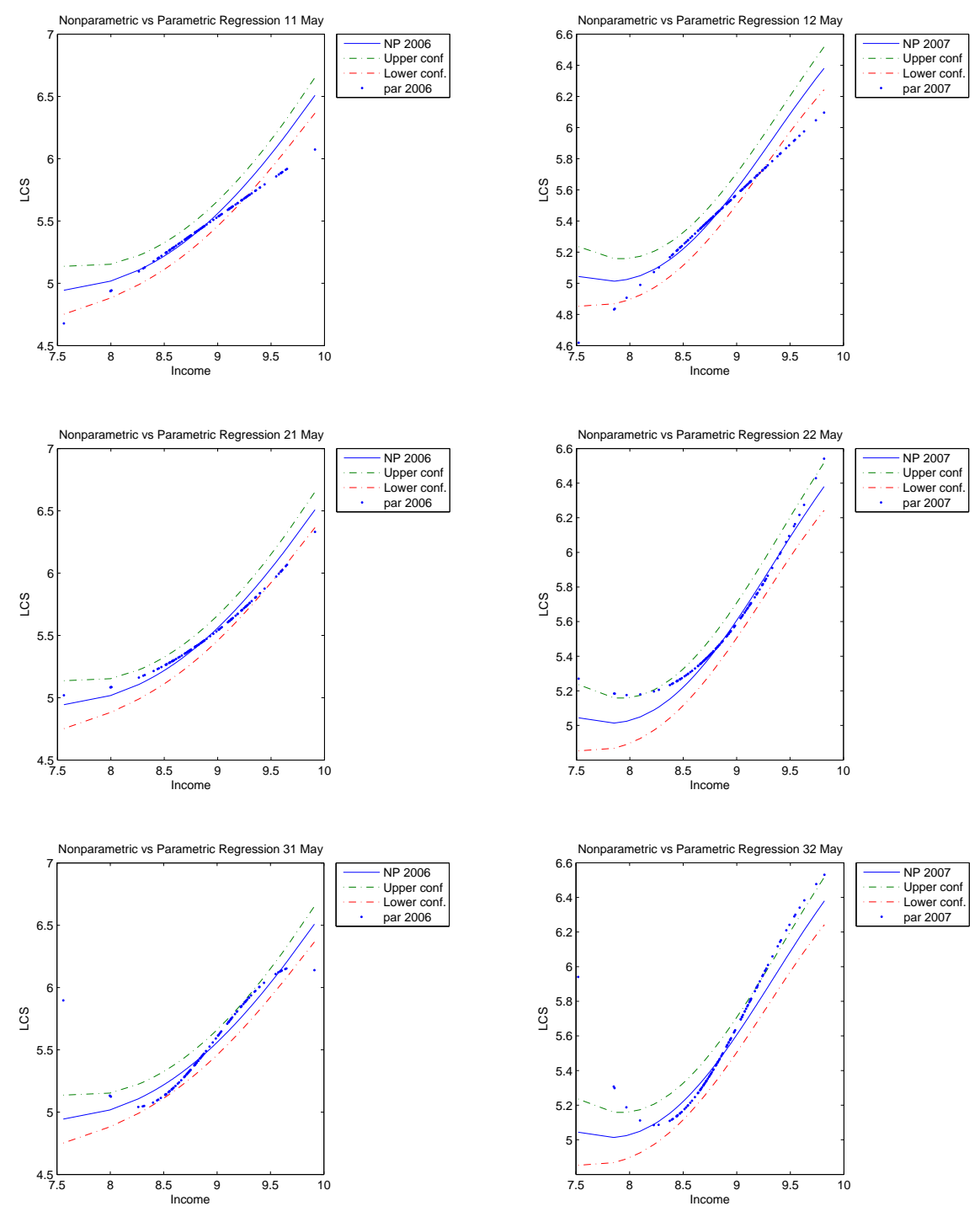

Figure 5: Parametric vs Nonparametric (Insurer): May. 

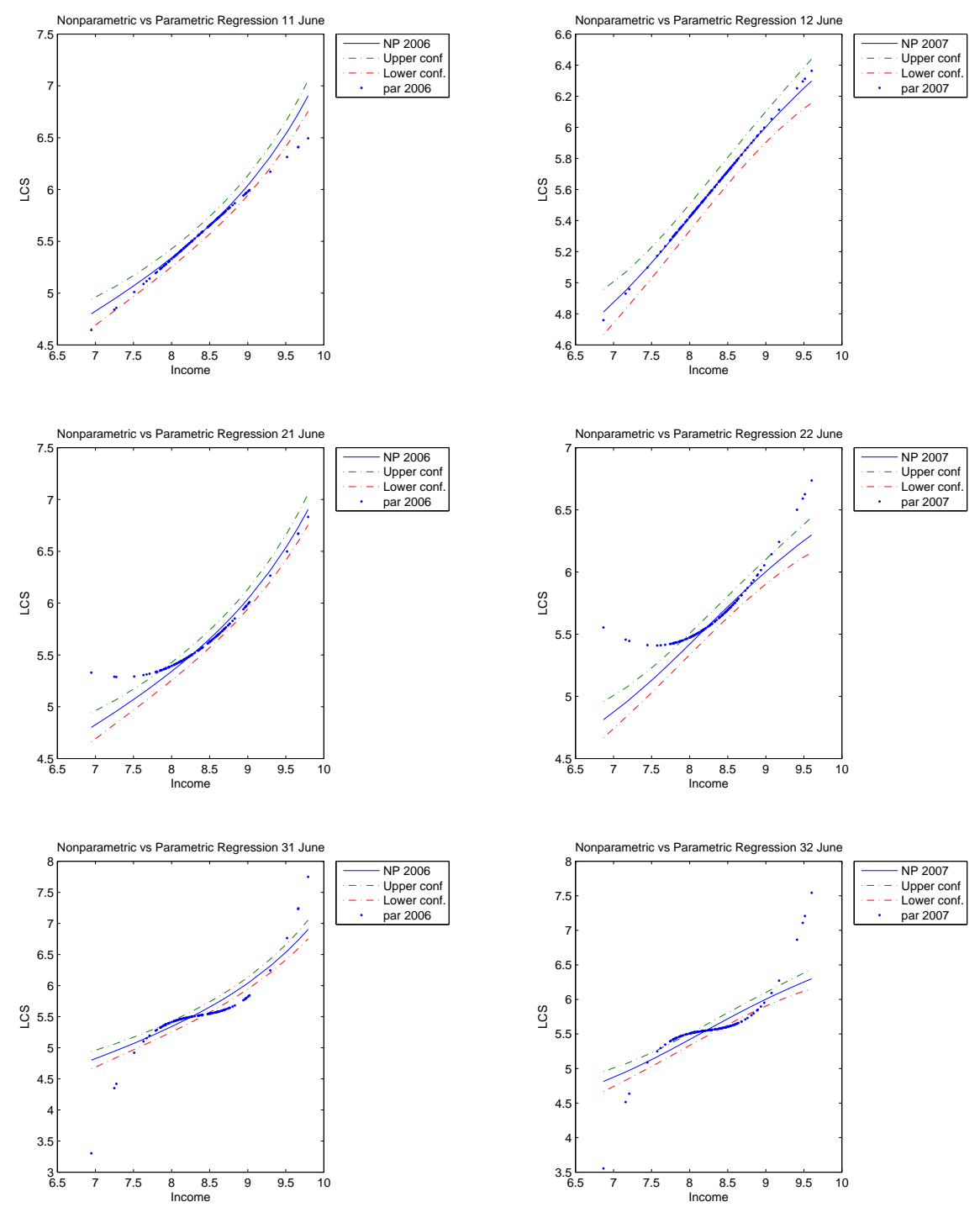

Figure 6: Parametric vs Nonparametric (Insurer): June. 

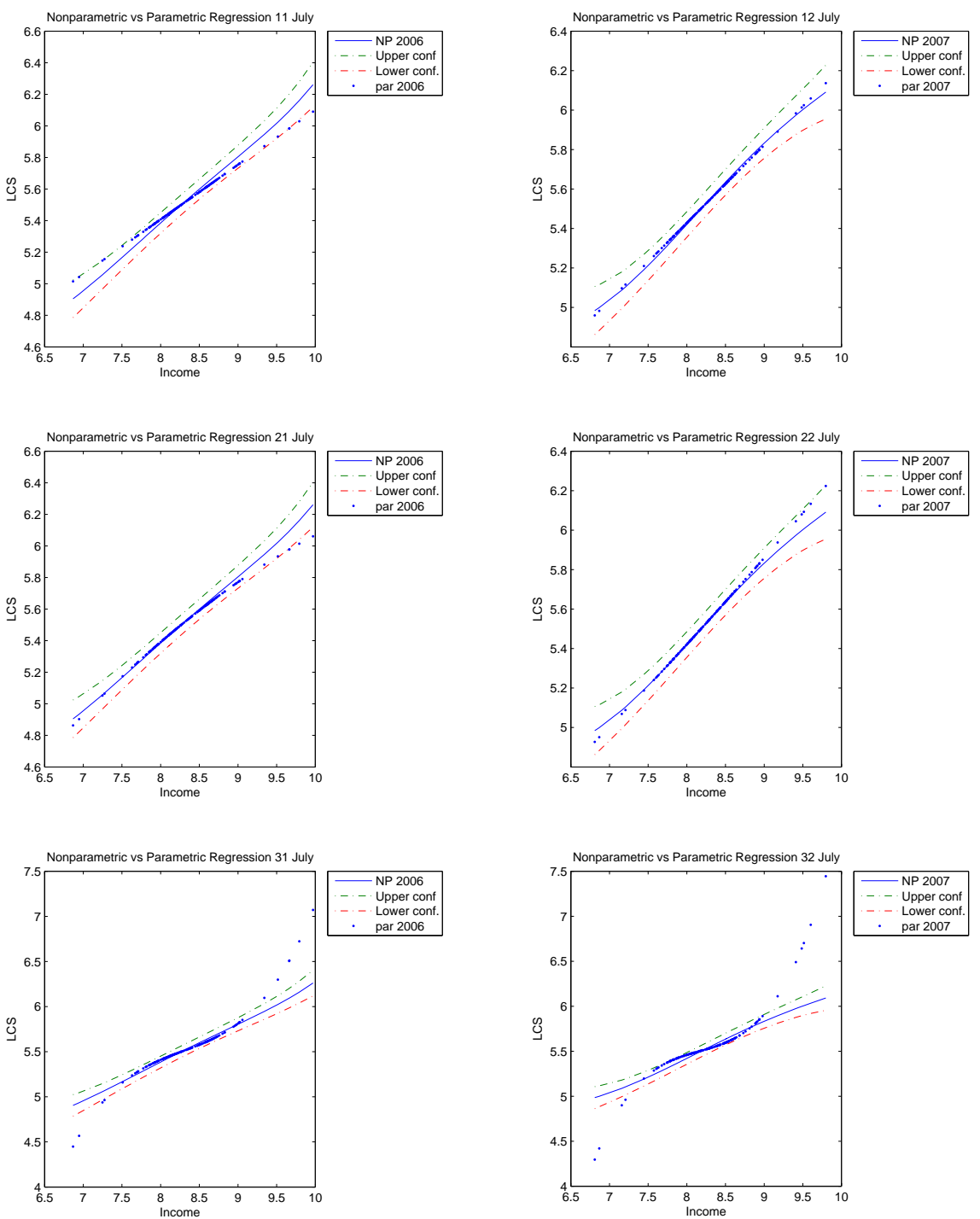

Figure 7: Parametric vs Nonparametric (Insurer): July. 

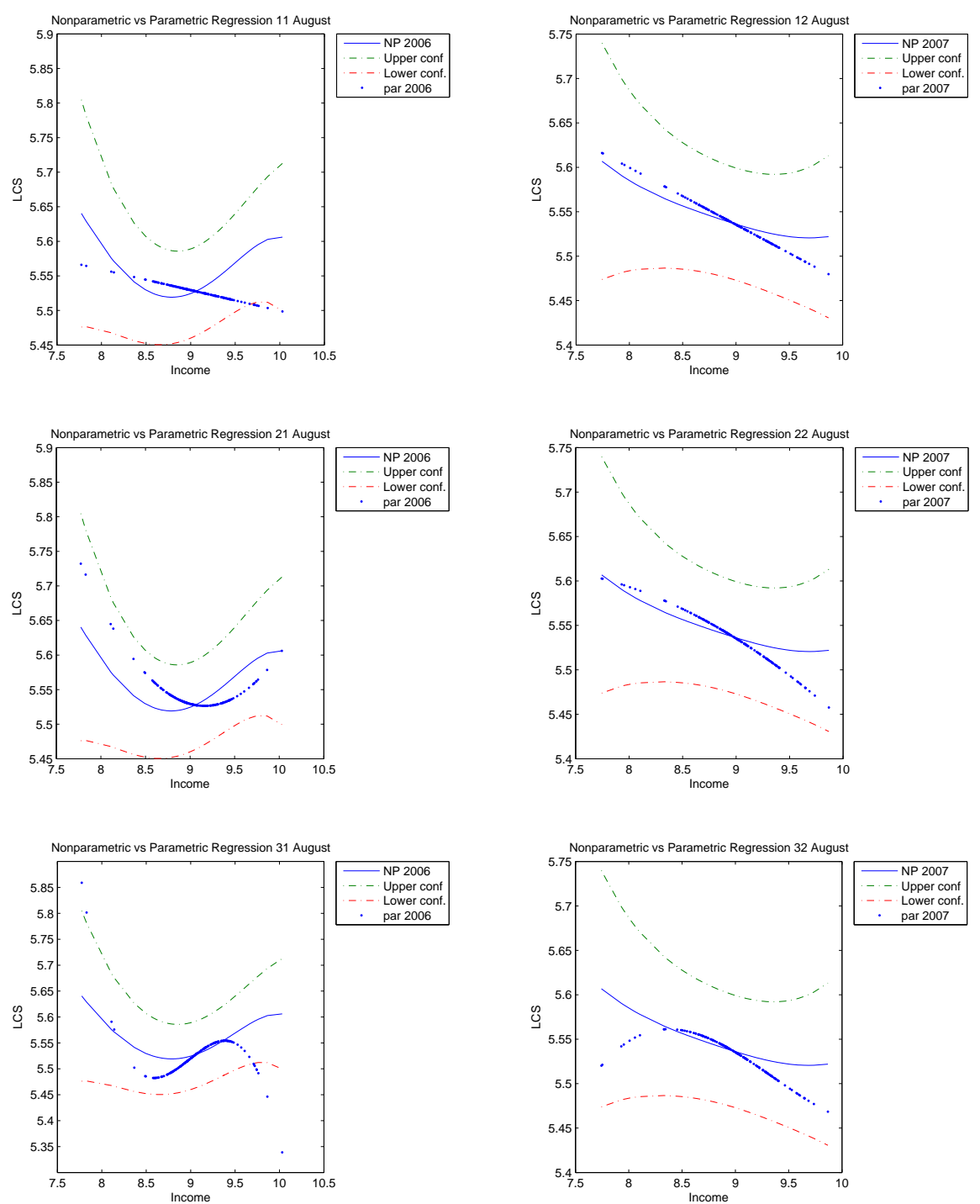

Figure 8: Parametric vs Nonparametric (Insurer): August. 

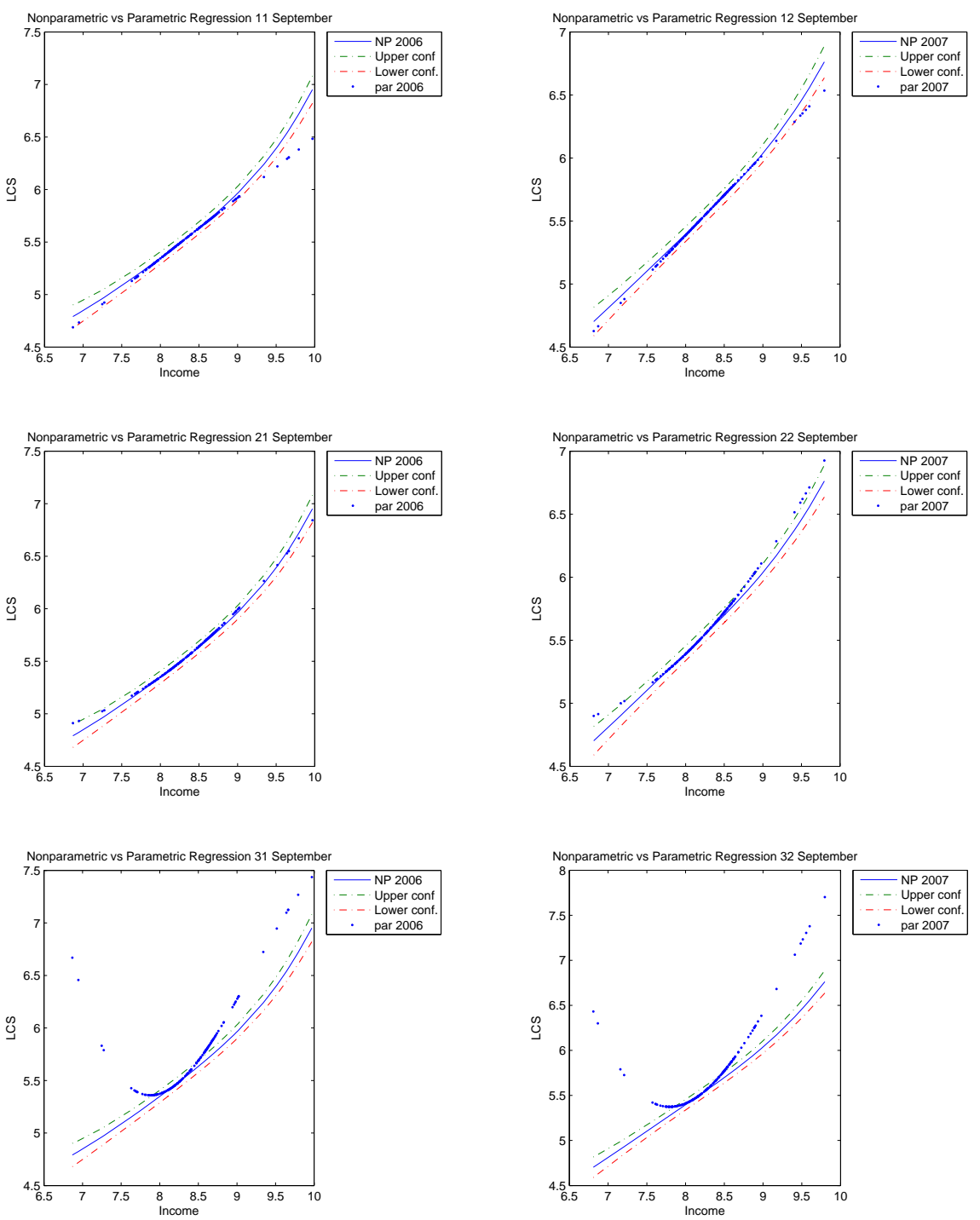

Figure 9: Parametric vs Nonparametric (Insurer): September. 

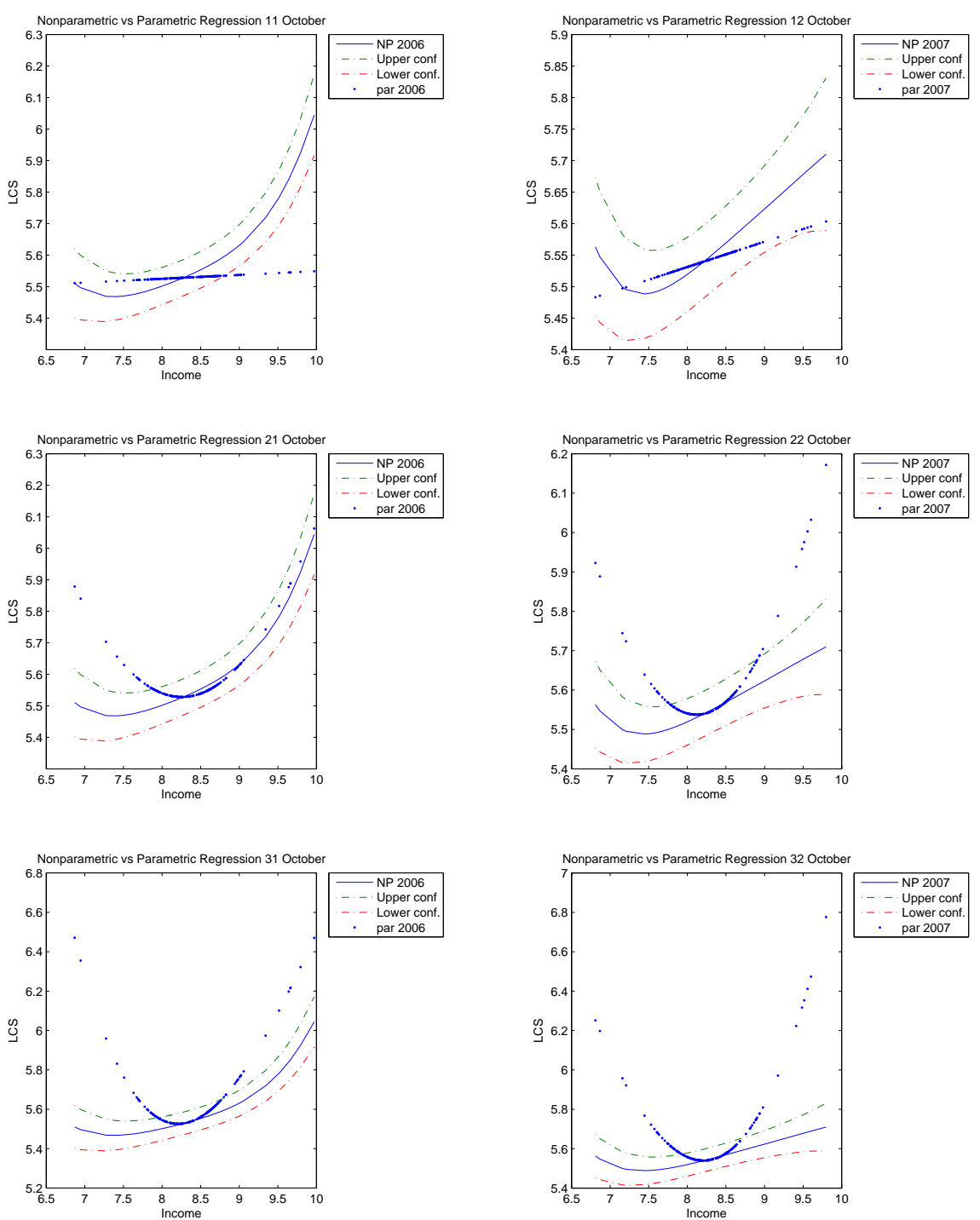

Figure 10: Parametric vs Nonparametric (Insurer): October. 

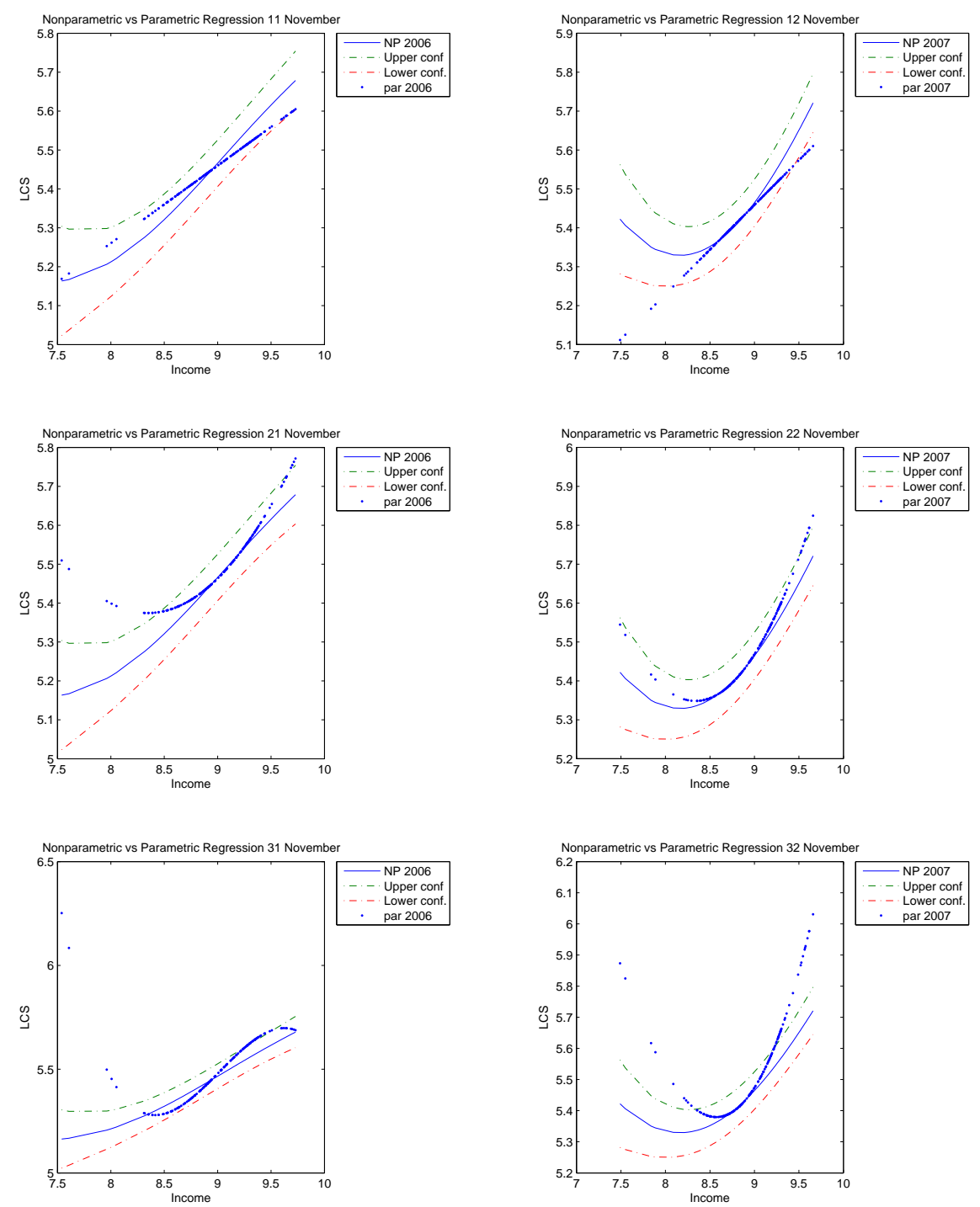

Figure 11: Parametric vs Nonparametric (Insurer): November. 

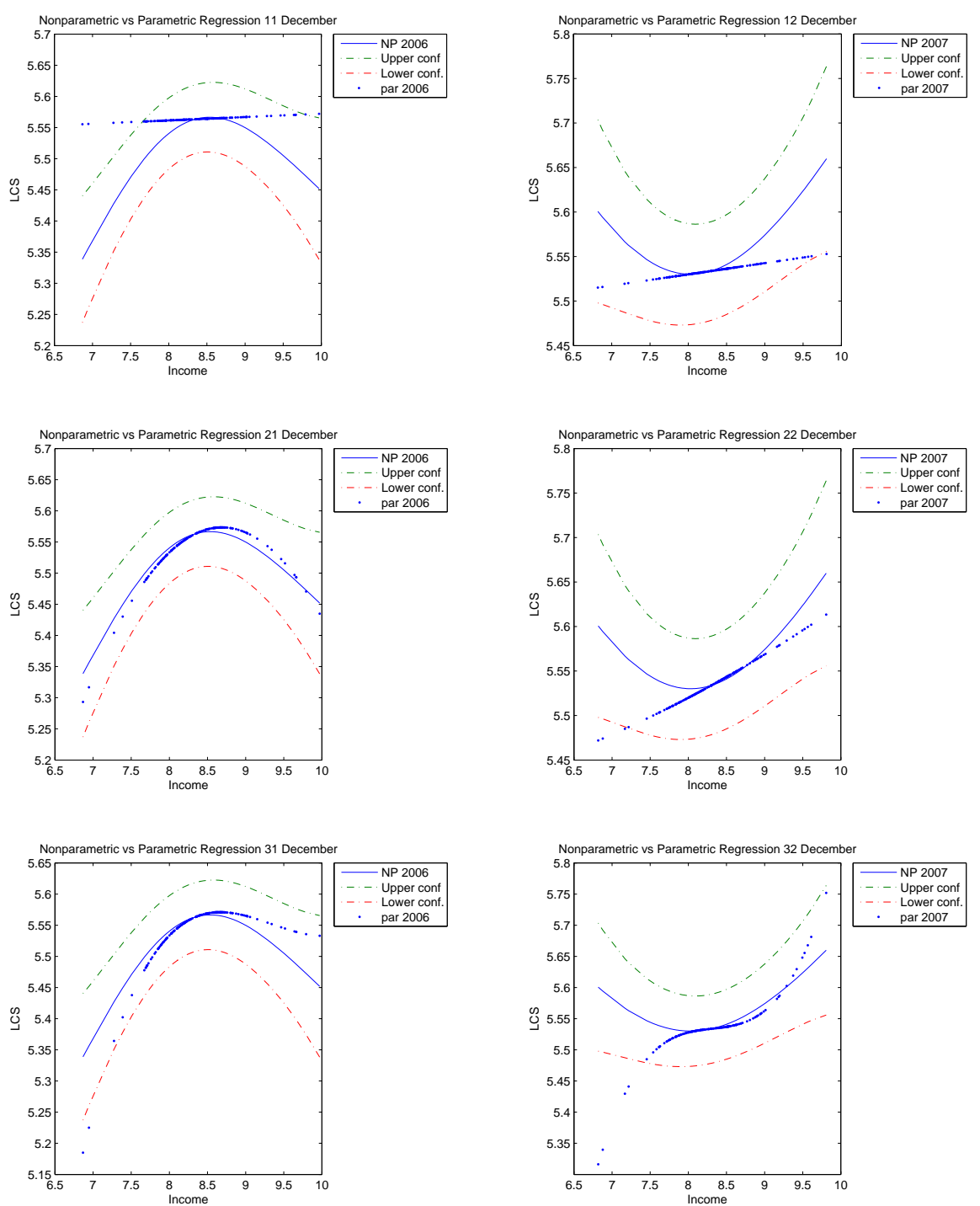

Figure 12: Parametric vs Nonparametric (Insurer): December. 

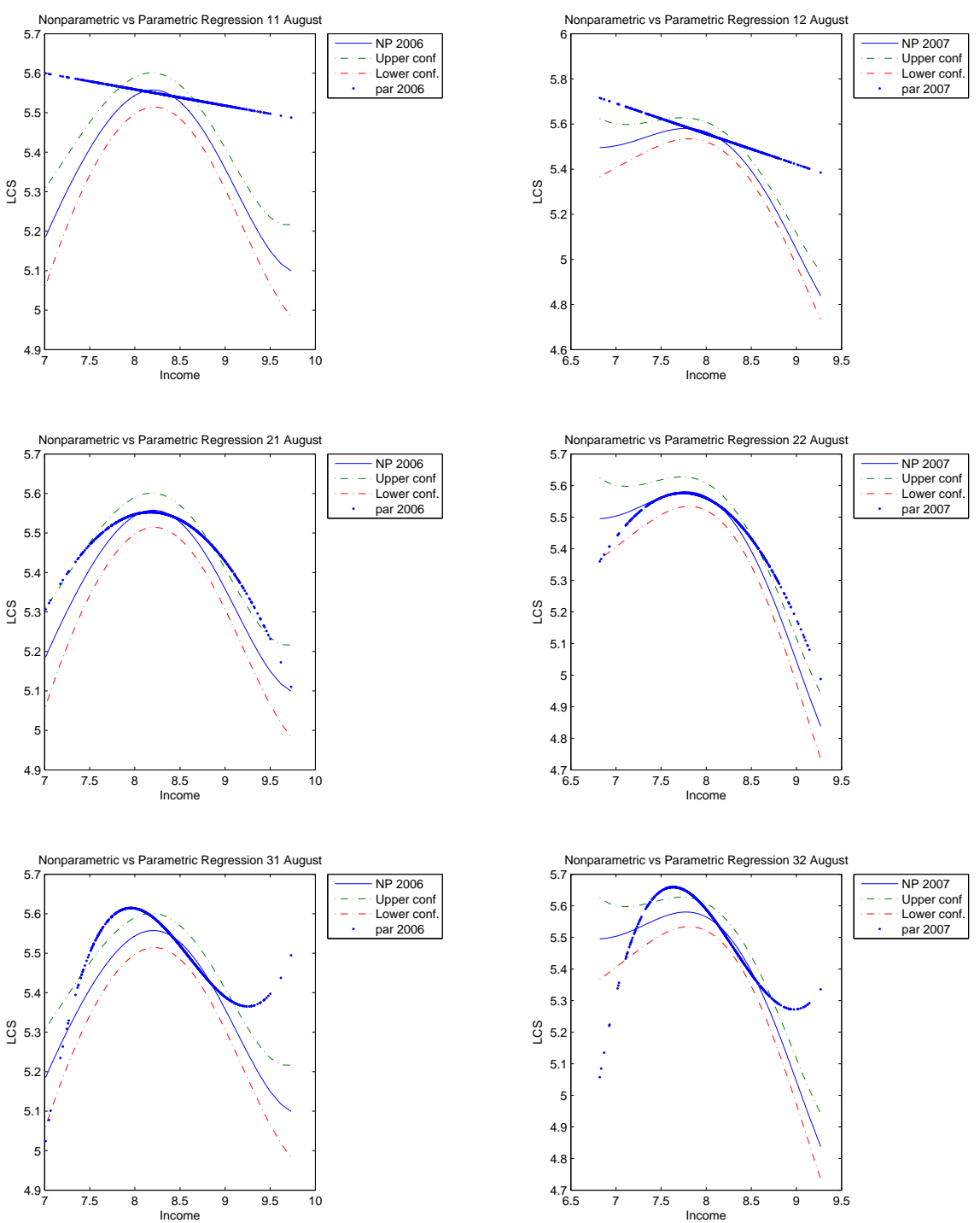

Figure 13: Parametric vs Nonparametric (Bank): August. 

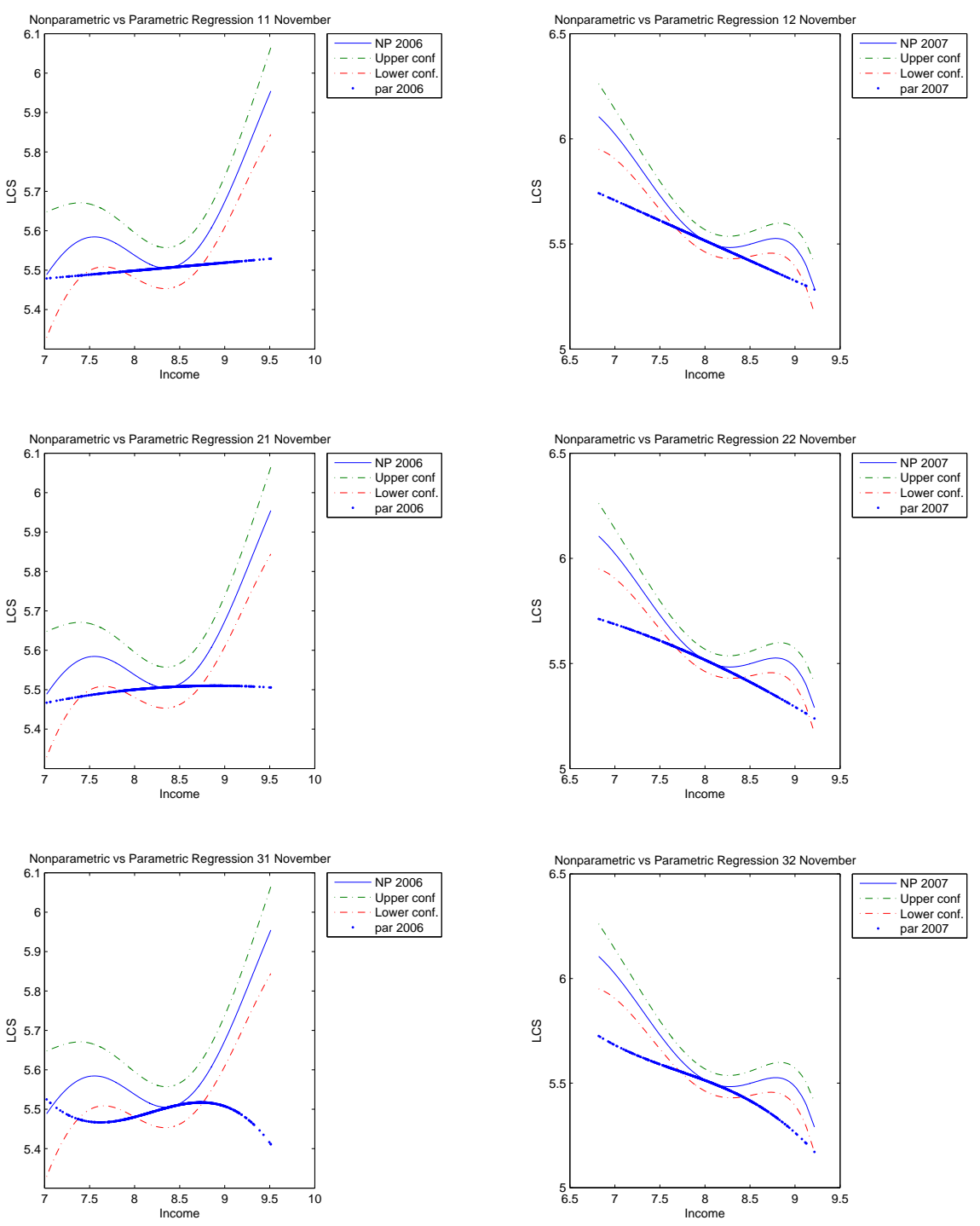

Figure 14: Parametric vs Nonparametric (Bank): November. 
Table 1: Summary Statistics

\begin{tabular}{|c|c|c|c|c|c|c|}
\hline \multirow[b]{2}{*}{ A. Entire Sample } & \multicolumn{3}{|c|}{ Bank } & \multicolumn{3}{|c|}{ Insurer } \\
\hline & 2005 & 2006 & 2007 & 2005 & 2006 & 2007 \\
\hline \multicolumn{7}{|l|}{ Participation } \\
\hline Life Course Savings Scheme & 0 & 0.077 & 0.076 & 0 & 0.062 & 0.074 \\
\hline Employee Savings Scheme & 0.476 & 0.354 & 0.373 & 0.816 & 0.645 & 0.680 \\
\hline \multicolumn{7}{|l|}{ Monthly inlay for participants } \\
\hline Life Course Savings Scheme & 0 & 327 & 385 & 0 & 339 & 401 \\
\hline Employee Savings Scheme & 52 & 51 & 48 & 48 & 47 & 47 \\
\hline \multicolumn{7}{|l|}{ Monthly wage components } \\
\hline Base salary & 2,897 & 2,978 & 3,093 & 3,223 & 3,271 & 3,449 \\
\hline Holiday allowance & 226 & 231 & 1 & 234 & 252 & 263 \\
\hline 13th month & 243 & 240 & 212 & 254 & 261 & 274 \\
\hline Profit share & 44 & 155 & 139 & 244 & 234 & 237 \\
\hline Overtime & 10 & 6 & 6 & 15 & 12 & 13 \\
\hline Bonus & 67 & 301 & 306 & 18 & 19 & 17 \\
\hline LCS contribution & 0 & 29 & 0 & 0 & 0 & 0 \\
\hline Other income & 41 & 56 & 39 & 32 & 105 & 133 \\
\hline Benefit scheme & 0 & 0 & 718 & 0 & 0 & 0 \\
\hline \multicolumn{7}{|l|}{ Employee characteristics } \\
\hline Age (years) & 41.3 & 41.5 & 41.8 & 42.9 & 42.1 & 41.8 \\
\hline Male (proportion) & 0.520 & 0.510 & 0.507 & 0.641 & 0.627 & 0.621 \\
\hline Person-month observations & 329,953 & 302,474 & 286,641 & 31,832 & 32,131 & 34,154 \\
\hline
\end{tabular}

Contributions to savings schemes and wage components are average monthly values in nominal Euro. Base salary is paid every month, Benefit scheme in most months for the Bank and Other income in most months for the Insurer. The other salary components are typically paid once a year. 


\begin{tabular}{lrrr|rrr}
\hline & & Bank & & Insurer \\
B. Subsample & 2005 & 2006 & 2007 & 2005 & 2006 & 2007 \\
\hline Inlay Life Course Savings (month) & - & 449 & 534 & - & 453 & 490 \\
& & & & & & \\
Wage components (month) & & & & & & \\
\hline Base salary & - & 3,537 & 3,791 & - & 4,083 & 4,320 \\
Holiday allowance & - & 320 & 0 & - & 268 & 274 \\
13th month & - & 188 & 193 & - & 421 & 447 \\
Profit share & - & 214 & 223 & - & 460 & 497 \\
Overtime & - & 5 & 4 & - & 7 & 7 \\
Bonus & - & 425 & 412 & - & 17 & 15 \\
LCS contribution & - & 43 & 0 & - & 0 & 0 \\
Other income & - & 46 & 19 & - & 166 & 253 \\
Benefit scheme & - & 0 & 960 & - & 0 & 0 \\
& & & & & & \\
Employee characteristics & - & & & & & 42.3 \\
\hline Age (years) & - & 43.3 & - & 45.6 & 46.6 \\
Male (proportion) & - & 9,569 & 9,569 & - & 1,518 & 1,518 \\
Person-month observations &
\end{tabular}

Panel B is a subsample of individuals with strictly positive contributions into the Life Course Savings scheme in the same month of years 2006 and 2007 (see section 3). Contributions to the Life Course Savings scheme and wage components are average monthly values in nominal Euro. Base salary is paid every month, Benefit scheme in most months for the Bank and Other income in most months for the Insurer. The other salary components are typically paid once a year. 
Table 2: $J=1$ Bank, fixed effects, controls for month and year included

\begin{tabular}{|c|c|c|c|c|c|c|c|}
\hline & $\begin{array}{l}\text { All } \\
\mathrm{b} / \mathrm{se}\end{array}$ & $\begin{array}{r}\text { Female } \\
\text { b/se }\end{array}$ & $\begin{array}{l}\text { Male } \\
\mathrm{b} / \mathrm{se}\end{array}$ & $\begin{array}{r}\text { Age }<45 \\
\text { b/se }\end{array}$ & $\begin{array}{r}\text { Age } \geq 45 \\
\mathrm{~b} / \mathrm{se}\end{array}$ & $\begin{array}{r}\text { Below median } \\
\mathrm{b} / \mathrm{se}\end{array}$ & $\begin{array}{r}\text { Above median } \\
\mathrm{b} / \mathrm{se}\end{array}$ \\
\hline Total income & $\begin{array}{r}0.030 \\
(0.03)\end{array}$ & $\begin{array}{r}0.118^{* * *} \\
(0.03)\end{array}$ & $\begin{array}{r}-0.015 \\
(0.03)\end{array}$ & $\begin{array}{r}0.036 \\
(0.03)\end{array}$ & $\begin{array}{r}0.039 \\
(0.05)\end{array}$ & $\begin{array}{r}0.030 \\
(0.03)\end{array}$ & $\begin{array}{r}0.034 \\
(0.03)\end{array}$ \\
\hline Holiday allowance & $\begin{array}{r}0.166^{* * *} \\
(0.03)\end{array}$ & $\begin{array}{r}0.077^{*} \\
(0.04)\end{array}$ & $\begin{array}{r}0.211^{* * *} \\
(0.03)\end{array}$ & $\begin{array}{r}0.091^{* *} \\
(0.03)\end{array}$ & $\begin{array}{r}0.223^{* * *} \\
(0.05)\end{array}$ & $\begin{array}{r}0.164^{* * *} \\
(0.04)\end{array}$ & $\begin{array}{r}0.168^{* * *} \\
(0.04)\end{array}$ \\
\hline 13th month & $\begin{array}{r}0.088^{*} \\
(0.04)\end{array}$ & $\begin{array}{r}-0.025 \\
(0.06)\end{array}$ & $\begin{array}{r}0.136^{*} \\
(0.05)\end{array}$ & $\begin{array}{c}0.034 \\
(0.05)\end{array}$ & $\begin{array}{r}0.097 \\
(0.07)\end{array}$ & $\begin{array}{r}0.080 \\
(0.07)\end{array}$ & $\begin{array}{r}0.031 \\
(0.07)\end{array}$ \\
\hline Profit share & $\begin{array}{r}-0.058^{*} \\
(0.03)\end{array}$ & $\begin{array}{r}-0.156^{* * *} \\
(0.04)\end{array}$ & $\begin{array}{l}-0.009 \\
(0.03)\end{array}$ & $\begin{array}{r}-0.046 \\
(0.03)\end{array}$ & $\begin{array}{r}-0.119^{*} \\
(0.05)\end{array}$ & $\begin{array}{r}-0.020 \\
(0.04)\end{array}$ & $\begin{array}{l}-0.057 \\
(0.04)\end{array}$ \\
\hline Overtime & $\begin{array}{r}-0.027 \\
(0.04)\end{array}$ & $\begin{array}{r}-0.141^{*} \\
(0.06)\end{array}$ & $\begin{array}{r}0.039 \\
(0.06)\end{array}$ & $\begin{array}{r}-0.001 \\
(0.07)\end{array}$ & $\begin{array}{r}-0.047 \\
(0.08)\end{array}$ & $\begin{array}{r}-0.056 \\
(0.05)\end{array}$ & $\begin{array}{r}-3.429^{* * *} \\
(0.45)\end{array}$ \\
\hline Bonus & $\begin{array}{r}-0.000 \\
(0.03)\end{array}$ & $\begin{array}{r}-0.129^{* * *} \\
(0.04)\end{array}$ & $\begin{array}{r}0.063 \\
(0.03)\end{array}$ & $\begin{array}{r}-0.018 \\
(0.03)\end{array}$ & $\begin{array}{r}0.004 \\
(0.05)\end{array}$ & $\begin{array}{r}-0.001 \\
(0.04)\end{array}$ & $\begin{array}{r}-0.002 \\
(0.03)\end{array}$ \\
\hline LCS contribution & $\begin{array}{r}0.534^{* * *} \\
(0.06)\end{array}$ & $\begin{array}{r}0.375^{* * *} \\
(0.08)\end{array}$ & $\begin{array}{r}0.621^{* * *} \\
(0.07)\end{array}$ & $\begin{array}{r}0.498^{* * *} \\
(0.06)\end{array}$ & $\begin{array}{r}0.563^{* * *} \\
(0.10)\end{array}$ & $\begin{array}{r}0.550^{* * *} \\
(0.06)\end{array}$ & $\begin{array}{r}0.609^{* * *} \\
(0.08)\end{array}$ \\
\hline Other income & $\begin{array}{r}-0.044 \\
(0.04)\end{array}$ & $\begin{array}{r}-0.125 \\
(0.07)\end{array}$ & $\begin{array}{r}0.001 \\
(0.05)\end{array}$ & $\begin{array}{r}-0.103^{* *} \\
(0.04)\end{array}$ & $\begin{array}{r}-0.007 \\
(0.07)\end{array}$ & $\begin{array}{r}-0.120 \\
(0.07)\end{array}$ & $\begin{array}{r}-0.049 \\
(0.05)\end{array}$ \\
\hline Benefit budget & $\begin{array}{r}0.146^{* *} \\
(0.05)\end{array}$ & $\begin{array}{r}0.071 \\
(0.07)\end{array}$ & $\begin{array}{l}0.170^{*} \\
(0.07)\end{array}$ & $\begin{array}{r}0.151^{* *} \\
(0.06)\end{array}$ & $\begin{array}{r}0.108 \\
(0.09)\end{array}$ & $\begin{array}{l}0.132^{*} \\
(0.06)\end{array}$ & $\begin{array}{r}-0.031 \\
(0.09)\end{array}$ \\
\hline February & $\begin{array}{r}66.974 \\
(86.82)\end{array}$ & $\begin{array}{r}32.266 \\
(112.35)\end{array}$ & $\begin{array}{r}61.176 \\
(151.06)\end{array}$ & $\begin{array}{r}-6.614 \\
(92.13)\end{array}$ & $\begin{array}{r}35.926 \\
(150.65)\end{array}$ & $\begin{array}{r}97.771 \\
(119.91)\end{array}$ & $\begin{array}{r}-216.496 \\
(283.19)\end{array}$ \\
\hline March & $\begin{array}{r}217.747^{*} \\
(87.45)\end{array}$ & $\begin{array}{r}167.156 \\
(117.10)\end{array}$ & $\begin{array}{r}221.403 \\
(150.88)\end{array}$ & $\begin{array}{r}175.873 \\
(97.72)\end{array}$ & $\begin{array}{r}142.228 \\
(148.52)\end{array}$ & $\begin{array}{r}165.881 \\
(120.84)\end{array}$ & $\begin{array}{r}31.150 \\
(285.96)\end{array}$ \\
\hline April & $\begin{array}{r}75.618 \\
(91.74)\end{array}$ & $\begin{array}{r}148.575 \\
(116.05)\end{array}$ & $\begin{array}{r}4.003 \\
(159.48)\end{array}$ & $\begin{array}{r}8.112 \\
(103.71)\end{array}$ & $\begin{array}{r}37.471 \\
(155.95)\end{array}$ & $\begin{array}{r}107.261 \\
(123.20)\end{array}$ & $\begin{array}{l}-242.799 \\
(294.79)\end{array}$ \\
\hline May & $\begin{array}{r}33.914 \\
(87.95)\end{array}$ & $\begin{array}{r}9.413 \\
(112.24)\end{array}$ & $\begin{array}{r}18.955 \\
(151.72)\end{array}$ & $\begin{array}{r}-71.937 \\
(104.41)\end{array}$ & $\begin{array}{r}144.376 \\
(142.78)\end{array}$ & $\begin{array}{r}9.839 \\
(123.38)\end{array}$ & $\begin{array}{r}-300.188 \\
(284.23)\end{array}$ \\
\hline June & $\begin{array}{r}74.046 \\
(85.51)\end{array}$ & $\begin{array}{r}38.499 \\
(114.15)\end{array}$ & $\begin{array}{r}66.351 \\
(148.89)\end{array}$ & $\begin{array}{r}25.167 \\
(95.03)\end{array}$ & $\begin{array}{r}9.298 \\
(145.73)\end{array}$ & $\begin{array}{r}108.347 \\
(120.71)\end{array}$ & $\begin{array}{r}-232.581 \\
(281.18)\end{array}$ \\
\hline July & $\begin{array}{r}9.052 \\
(86.73)\end{array}$ & $\begin{array}{r}2.762 \\
(112.35)\end{array}$ & $\begin{array}{r}-20.783 \\
(151.28)\end{array}$ & $\begin{array}{r}-38.938 \\
(93.35)\end{array}$ & $\begin{array}{r}-54.229 \\
(149.76)\end{array}$ & $\begin{array}{r}64.563 \\
(119.96)\end{array}$ & $\begin{array}{r}-346.514 \\
(285.78)\end{array}$ \\
\hline August & $\begin{array}{r}84.545 \\
(86.48)\end{array}$ & $\begin{array}{r}38.114 \\
(115.07)\end{array}$ & $\begin{array}{r}86.241 \\
(150.57)\end{array}$ & $\begin{array}{r}20.623 \\
(95.12)\end{array}$ & $\begin{array}{r}44.907 \\
(148.49)\end{array}$ & $\begin{array}{r}110.983 \\
(120.92)\end{array}$ & $\begin{array}{r}-211.288 \\
(284.10)\end{array}$ \\
\hline September & $\begin{array}{r}81.885 \\
(87.15)\end{array}$ & $\begin{array}{r}36.750 \\
(114.05)\end{array}$ & $\begin{array}{r}81.905 \\
(152.08)\end{array}$ & $\begin{array}{r}15.068 \\
(94.86)\end{array}$ & $\begin{array}{r}40.836 \\
(150.68)\end{array}$ & $\begin{array}{r}104.358 \\
(120.76)\end{array}$ & $\begin{array}{r}-208.959 \\
(286.06)\end{array}$ \\
\hline October & $\begin{array}{r}82.073 \\
(87.20)\end{array}$ & $\begin{array}{r}40.410 \\
(115.06)\end{array}$ & $\begin{array}{r}79.896 \\
(151.72)\end{array}$ & $\begin{array}{r}15.598 \\
(95.32)\end{array}$ & $\begin{array}{r}39.895 \\
(149.92)\end{array}$ & $\begin{array}{r}99.952 \\
(120.84)\end{array}$ & $\begin{array}{r}-200.930 \\
(285.42)\end{array}$ \\
\hline November & $\begin{array}{r}149.083 \\
(87.88)\end{array}$ & $\begin{array}{r}86.292 \\
(115.68)\end{array}$ & $\begin{array}{r}162.281 \\
(152.31)\end{array}$ & $\begin{array}{r}97.064 \\
(96.73)\end{array}$ & $\begin{array}{r}82.298 \\
(150.83)\end{array}$ & $\begin{array}{r}127.216 \\
(120.97)\end{array}$ & $\begin{array}{r}-76.683 \\
(286.06)\end{array}$ \\
\hline December & $\begin{array}{r}127.461 \\
(87.95)\end{array}$ & $\begin{array}{r}83.286 \\
(115.76)\end{array}$ & $\begin{array}{r}127.544 \\
(152.78)\end{array}$ & $\begin{array}{r}48.047 \\
(95.67)\end{array}$ & $\begin{array}{r}105.815 \\
(151.58)\end{array}$ & $\begin{array}{r}115.129 \\
(120.85)\end{array}$ & $\begin{array}{r}-110.885 \\
(286.99)\end{array}$ \\
\hline Year 2007 & $\begin{array}{r}-4.932 \\
(32.13)\end{array}$ & $\begin{array}{r}-41.330 \\
(31.07)\end{array}$ & $\begin{array}{r}43.233 \\
(60.78)\end{array}$ & $\begin{array}{r}-43.637 \\
(26.92)\end{array}$ & $\begin{array}{r}57.761 \\
(61.97)\end{array}$ & $\begin{array}{r}-26.260 \\
(29.59)\end{array}$ & $\begin{array}{r}271.570^{*} \\
(105.61)\end{array}$ \\
\hline Constant & $\begin{array}{r}144.767 \\
(124.71)\end{array}$ & $\begin{array}{r}-152.164 \\
(154.45)\end{array}$ & $\begin{array}{r}391.152^{*} \\
(185.64)\end{array}$ & $\begin{array}{r}75.481 \\
(121.74)\end{array}$ & $\begin{array}{r}306.490 \\
(249.39)\end{array}$ & $\begin{array}{r}35.830 \\
(139.51)\end{array}$ & $\begin{array}{r}528.680 \\
(310.93)\end{array}$ \\
\hline$R^{2}$ & 0.068 & 0.070 & 0.070 & 0.053 & 0.091 & 0.061 & 0.077 \\
\hline$N$ person $\times$ month & 19138 & 8000 & 11138 & 11377 & 8234 & 10984 & 8154 \\
\hline$F$-stat & 30.49 & 13.67 & 20.15 & 21.78 & 17.22 & 19.32 & 70.67 \\
\hline$p$-value & 0.000 & 0.000 & 0.000 & 0.000 & 0.000 & 0.000 & 0.000 \\
\hline
\end{tabular}


Table 3: $J=1$ Insurer, fixed effects, controls for month and year included

\begin{tabular}{|c|c|c|c|c|c|c|c|}
\hline & $\begin{array}{l}\text { All } \\
\mathrm{b} / \mathrm{se}\end{array}$ & $\begin{array}{l}\text { Female } \\
\mathrm{b} / \mathrm{se}\end{array}$ & $\begin{array}{l}\text { Male } \\
\mathrm{b} / \mathrm{se}\end{array}$ & $\begin{array}{r}\text { Age }<45 \\
\mathrm{~b} / \mathrm{se}\end{array}$ & $\begin{array}{r}\text { Age } \geq 45 \\
\mathrm{~b} / \mathrm{se}\end{array}$ & $\begin{array}{r}\text { Below median } \\
\mathrm{b} / \mathrm{se}\end{array}$ & $\begin{array}{r}\text { Above median } \\
\mathrm{b} / \mathrm{se}\end{array}$ \\
\hline \multirow[t]{2}{*}{ Total income } & 0.034 & -0.015 & 0.032 & -0.061 & 0.186 & 0.036 & 0.001 \\
\hline & $(0.06)$ & $(0.02)$ & $(0.07)$ & $(0.04)$ & $(0.12)$ & $(0.02)$ & $(0.07)$ \\
\hline \multirow[t]{2}{*}{ Holiday allowance } & -0.027 & 0.014 & -0.025 & 0.065 & -0.171 & -0.034 & -0.005 \\
\hline & $(0.06)$ & $(0.02)$ & $(0.07)$ & $(0.04)$ & $(0.11)$ & $(0.03)$ & $(0.07)$ \\
\hline \multirow[t]{2}{*}{13 th month } & -0.026 & 0.015 & -0.022 & 0.063 & -0.175 & -0.036 & 0.013 \\
\hline & $(0.06)$ & $(0.02)$ & $(0.07)$ & $(0.04)$ & $(0.12)$ & $(0.02)$ & $(0.08)$ \\
\hline \multirow[t]{2}{*}{ Profit share } & -0.031 & 0.015 & -0.029 & 0.064 & -0.186 & -0.037 & 0.000 \\
\hline & $(0.06)$ & $(0.02)$ & $(0.07)$ & $(0.04)$ & $(0.12)$ & $(0.02)$ & $(0.07)$ \\
\hline \multirow[t]{2}{*}{ Overtime } & -0.126 & -0.018 & -0.142 & 0.023 & $-0.277^{*}$ & -0.101 & -0.275 \\
\hline & $(0.08)$ & $(0.03)$ & $(0.10)$ & $(0.05)$ & $(0.14)$ & $(0.06)$ & $(0.23)$ \\
\hline \multirow[t]{2}{*}{ Bonus } & -0.035 & 0.007 & -0.032 & 0.059 & -0.187 & & 0.000 \\
\hline & $(0.06)$ & $(0.02)$ & $(0.07)$ & $(0.04)$ & $(0.12)$ & & $(0.07)$ \\
\hline \multirow[t]{2}{*}{ Other income } & 0.011 & 0.015 & 0.022 & 0.057 & -0.070 & -0.016 & 0.045 \\
\hline & $(0.06)$ & $(0.02)$ & $(0.08)$ & $(0.04)$ & $(0.16)$ & $(0.02)$ & $(0.08)$ \\
\hline \multirow[t]{2}{*}{ February } & 12.014 & 48.871 & -0.389 & -14.578 & 23.473 & 29.716 & -7.458 \\
\hline & (18.98) & $(30.83)$ & (18.75) & $(31.28)$ & $(23.82)$ & (16.77) & $(25.71)$ \\
\hline \multirow[t]{2}{*}{ March } & 0.822 & 6.234 & -2.538 & -7.282 & 4.840 & 3.129 & -6.024 \\
\hline & (19.70) & (15.57) & $(21.32)$ & $(31.52)$ & $(23.22)$ & (12.06) & $(28.90)$ \\
\hline \multirow[t]{2}{*}{ April } & -7.132 & 1.838 & -12.756 & -15.668 & -11.312 & 2.567 & -19.741 \\
\hline & (20.13) & (13.28) & $(22.10)$ & $(31.39)$ & $(27.31)$ & (12.07) & $(30.09)$ \\
\hline \multirow[t]{2}{*}{ May } & -17.848 & -3.298 & -19.117 & -21.483 & -40.435 & -11.863 & 50.091 \\
\hline & (19.14) & $(7.37)$ & $(24.11)$ & $(26.66)$ & $(29.64)$ & (14.97) & $(42.89)$ \\
\hline \multirow[t]{2}{*}{ June } & -9.589 & -6.427 & -11.120 & -20.744 & -18.696 & $-14.228^{*}$ & -0.189 \\
\hline & $(25.35)$ & $(3.58)$ & $(29.16)$ & $(30.12)$ & $(38.21)$ & $(5.65)$ & (43.28) \\
\hline \multirow[t]{2}{*}{ July } & 1.628 & -5.497 & 2.335 & -18.649 & -3.221 & -8.488 & 17.470 \\
\hline & (23.01) & $(3.65)$ & (25.98) & $(30.00)$ & $(32.27)$ & $(5.61)$ & $(39.09)$ \\
\hline \multirow[t]{2}{*}{ August } & -8.529 & -5.692 & -12.228 & -27.262 & 1.140 & -4.988 & 13.223 \\
\hline & $(23.24)$ & $(3.81)$ & $(27.68)$ & $(32.80)$ & $(27.65)$ & $(9.24)$ & $(40.85)$ \\
\hline \multirow[t]{2}{*}{ September } & 3.166 & -5.891 & 4.325 & -18.120 & -0.390 & -6.502 & 18.926 \\
\hline & $(24.00)$ & $(3.70)$ & $(27.35)$ & $(29.92)$ & $(33.26)$ & $(6.33)$ & (41.43) \\
\hline \multirow[t]{2}{*}{ October } & 3.557 & -6.131 & 4.675 & -17.019 & -1.202 & -6.313 & 19.979 \\
\hline & $(24.18)$ & $(3.72)$ & $(27.65)$ & $(30.31)$ & $(33.91)$ & $(6.06)$ & (41.90) \\
\hline \multirow[t]{2}{*}{ November } & -28.237 & -3.894 & -40.664 & -24.138 & -46.970 & -8.839 & -53.251 \\
\hline & (19.78) & $(5.25)$ & $(24.46)$ & $(26.30)$ & $(32.73)$ & $(6.72)$ & $(53.56)$ \\
\hline \multirow[t]{2}{*}{ December } & -4.038 & -4.641 & -3.911 & -15.037 & -19.074 & -7.620 & 7.877 \\
\hline & $(25.49)$ & $(3.75)$ & $(29.50)$ & $(30.61)$ & $(39.38)$ & $(5.31)$ & $(44.44)$ \\
\hline \multirow[t]{2}{*}{ Year 2007} & 24.760 & 0.083 & 34.412 & -0.615 & 21.670 & 7.751 & 56.911 \\
\hline & $(15.63)$ & $(6.99)$ & $(21.54)$ & (13.44) & $(23.62)$ & $(8.36)$ & $(36.43)$ \\
\hline \multirow[t]{2}{*}{ Constant } & 307.764 & $270.565^{* * *}$ & 374.579 & $504.162^{* *}$ & -199.788 & $210.385^{* * *}$ & 583.807 \\
\hline & $(246.43)$ & $(45.92)$ & $(325.65)$ & $(175.80)$ & $(483.54)$ & $(58.39)$ & $(403.08)$ \\
\hline$R^{2}$ & 0.038 & 0.037 & 0.050 & 0.063 & 0.127 & 0.024 & 0.055 \\
\hline$N$ person $\times$ month & 3036 & 740 & 2296 & 1294 & 1859 & 1582 & 1454 \\
\hline$F$-stat & 1.52 & 1.53 & 1.30 & 1.35 & 1.91 & 2.26 & 1.19 \\
\hline$p$-value & 0.174 & 0.191 & 0.262 & 0.244 & 0.086 & 0.054 & 0.321 \\
\hline
\end{tabular}


Table 4: $J=1$ Bank, annual data, fixed effects

\begin{tabular}{|c|c|c|c|c|c|c|c|}
\hline & $\begin{array}{l}\text { All } \\
\mathrm{b} / \mathrm{se}\end{array}$ & $\begin{array}{r}\text { Female } \\
\mathrm{b} / \mathrm{se}\end{array}$ & $\begin{array}{l}\text { Male } \\
\mathrm{b} / \mathrm{se}\end{array}$ & $\begin{array}{r}\text { Age }<45 \\
\mathrm{~b} / \mathrm{se}\end{array}$ & $\begin{array}{r}\text { Age } \geq 45 \\
\mathrm{~b} / \mathrm{se}\end{array}$ & $\begin{array}{r}\text { Below median } \\
\mathrm{b} / \mathrm{se}\end{array}$ & $\begin{array}{r}\text { Above median } \\
\mathrm{b} / \mathrm{se}\end{array}$ \\
\hline Total income & $\begin{array}{c}-0.019 \\
(0.02)\end{array}$ & $\begin{array}{r}0.019 \\
(0.02)\end{array}$ & $\begin{array}{r}-0.049 \\
(0.03)\end{array}$ & $\begin{array}{r}0.004 \\
(0.01)\end{array}$ & $\begin{array}{r}-0.045 \\
(0.06)\end{array}$ & $\begin{array}{r}0.001 \\
(0.02)\end{array}$ & $\begin{array}{r}-0.012 \\
(0.04)\end{array}$ \\
\hline Holiday allowance & $\begin{array}{r}0.833^{* *} \\
(0.26)\end{array}$ & $\begin{array}{r}1.005^{* *} \\
(0.31)\end{array}$ & $\begin{array}{c}0.763^{*} \\
(0.32)\end{array}$ & $\begin{array}{l}0.306 \\
(0.19)\end{array}$ & $\begin{array}{r}1.253^{* *} \\
(0.41)\end{array}$ & $\begin{array}{l}0.441 \\
(0.27)\end{array}$ & $\begin{array}{r}1.001^{* *} \\
(0.32)\end{array}$ \\
\hline 13 th month & $\begin{array}{r}0.095 \\
(0.10)\end{array}$ & $\begin{array}{r}-0.060 \\
(0.08)\end{array}$ & $\begin{array}{r}0.150 \\
(0.14)\end{array}$ & $\begin{array}{r}0.110 \\
(0.07)\end{array}$ & $\begin{array}{r}0.097 \\
(0.22)\end{array}$ & $\begin{array}{r}0.029 \\
(0.08)\end{array}$ & $\begin{array}{r}0.101 \\
(0.14)\end{array}$ \\
\hline Profit share & $\begin{array}{r}0.061 \\
(0.13)\end{array}$ & $\begin{array}{c}-0.388 \\
(0.23)\end{array}$ & $\begin{array}{l}0.241 \\
(0.14)\end{array}$ & $\begin{array}{r}0.081 \\
(0.16)\end{array}$ & $\begin{array}{l}-0.115 \\
(0.23)\end{array}$ & $\begin{array}{r}0.190 \\
(0.19)\end{array}$ & $\begin{array}{r}-0.013 \\
(0.15)\end{array}$ \\
\hline Overtime & $\begin{array}{r}0.218^{* *} \\
(0.07)\end{array}$ & $\begin{array}{c}0.243^{*} \\
(0.11)\end{array}$ & $\begin{array}{l}0.357 \\
(0.25)\end{array}$ & $\begin{array}{r}0.140 \\
(0.17)\end{array}$ & $\begin{array}{r}0.260 \\
(0.19)\end{array}$ & $\begin{array}{c}0.152^{*} \\
(0.06)\end{array}$ & $\begin{array}{r}2.383 \\
(1.53)\end{array}$ \\
\hline Bonus & $\begin{array}{r}0.054 \\
(0.05)\end{array}$ & $\begin{array}{l}-0.063 \\
(0.05)\end{array}$ & $\begin{array}{r}0.120 \\
(0.07)\end{array}$ & $\begin{array}{l}-0.009 \\
(0.04)\end{array}$ & $\begin{array}{r}0.160 \\
(0.12)\end{array}$ & $\begin{array}{r}0.072 \\
(0.06)\end{array}$ & $\begin{array}{r}0.033 \\
(0.07)\end{array}$ \\
\hline LCS contribution & $\begin{array}{c}2.065 \\
(1.73)\end{array}$ & $\begin{array}{l}-1.258 \\
(1.52)\end{array}$ & $\begin{array}{l}5.186 \\
(2.88)\end{array}$ & $\begin{array}{l}1.768^{*} \\
(0.81)\end{array}$ & $\begin{array}{r}3.749 \\
(4.84)\end{array}$ & $\begin{array}{l}1.066 \\
(0.97)\end{array}$ & $\begin{array}{r}2.594 \\
(2.83)\end{array}$ \\
\hline Other income & $\begin{array}{r}0.075 \\
(0.09)\end{array}$ & $\begin{array}{r}0.146 \\
(0.18)\end{array}$ & $\begin{array}{r}0.087 \\
(0.11)\end{array}$ & $\begin{array}{r}0.033 \\
(0.07)\end{array}$ & $\begin{array}{c}0.078 \\
(0.32)\end{array}$ & $\begin{array}{r}0.055 \\
(0.08)\end{array}$ & $\begin{array}{r}0.053 \\
(0.11)\end{array}$ \\
\hline Benefit budget & $\begin{array}{r}0.382^{* * *} \\
(0.10)\end{array}$ & $\begin{array}{r}0.334^{* *} \\
(0.12)\end{array}$ & $\begin{array}{r}0.482^{* * *} \\
\quad(0.14)\end{array}$ & $\begin{array}{r}0.220^{* *} \\
(0.08)\end{array}$ & $\begin{array}{r}0.576^{*} \\
(0.26)\end{array}$ & $\begin{array}{r}0.225 \\
(0.12)\end{array}$ & $\begin{array}{r}0.324^{*} \\
(0.16)\end{array}$ \\
\hline year 2007 & $\begin{array}{r}360.255 \\
(262.00)\end{array}$ & $\begin{array}{r}-164.547 \\
(265.29)\end{array}$ & $\begin{array}{r}700.193 \\
(512.26)\end{array}$ & $\begin{array}{r}40.633 \\
(224.52)\end{array}$ & $\begin{array}{r}521.711 \\
(599.45)\end{array}$ & $\begin{array}{r}-50.282 \\
(257.24)\end{array}$ & $\begin{array}{r}2374.061^{*} \\
(943.09)\end{array}$ \\
\hline Constant & $\begin{array}{r}677.010 \\
(716.87) \\
\end{array}$ & $\begin{array}{r}694.011 \\
(485.82)\end{array}$ & $\begin{array}{r}732.548 \\
(977.15)\end{array}$ & $\begin{array}{r}372.552 \\
(410.43)\end{array}$ & $\begin{array}{r}1489.631 \\
(1692.35)\end{array}$ & $\begin{array}{r}550.993 \\
(433.25)\end{array}$ & $\begin{array}{r}-45.060 \\
(1350.34) \\
\end{array}$ \\
\hline$R^{2}$ & 0.074 & 0.135 & 0.079 & 0.098 & 0.083 & 0.072 & 0.086 \\
\hline$N$ & 3224 & 1334 & 1890 & 1950 & 1373 & 1612 & 1612 \\
\hline$F$-stat & 4.29 & 4.46 & 3.54 & 2.31 & 2.52 & 2.07 & 3.39 \\
\hline$p$-value & 0.000 & 0.000 & 0.000 & 0.019 & 0.010 & 0.037 & 0.001 \\
\hline
\end{tabular}

Table 5: $J=1$ Insurer, annual data, fixed effects

\begin{tabular}{lrrrrrrr}
\hline & \multicolumn{1}{c}{$\begin{array}{c}\text { All } \\
\mathrm{b} / \mathrm{se}\end{array}$} & $\begin{array}{r}\text { Female } \\
\mathrm{b} / \mathrm{se}\end{array}$ & $\begin{array}{r}\text { Male } \\
\mathrm{b} / \mathrm{se}\end{array}$ & $\begin{array}{r}\text { Age }<45 \\
\mathrm{~b} / \mathrm{se}\end{array}$ & $\begin{array}{r}\text { Age } \geq 45 \\
\mathrm{~b} / \mathrm{se}\end{array}$ & $\begin{array}{r}\text { Below median } \\
\mathrm{b} / \mathrm{se}\end{array}$ & $\begin{array}{r}\text { Above median } \\
\mathrm{b} / \mathrm{se}\end{array}$ \\
\hline Total income & 0.065 & 0.003 & 0.063 & 0.024 & 0.194 & 0.034 & -0.019 \\
& $(0.10)$ & $(0.07)$ & $(0.15)$ & $(0.03)$ & $(0.24)$ & $(0.09)$ & $(0.13)$ \\
Holiday allowance & 1.119 & 0.364 & 1.326 & 0.522 & 0.253 & $2.336^{* *}$ & 0.307 \\
& $(0.96)$ & $(0.68)$ & $(1.53)$ & $(0.41)$ & $(1.87)$ & $(0.86)$ & $(1.08)$ \\
13th month & 0.261 & 0.194 & 0.303 & 0.054 & -0.072 & -0.156 & 0.398 \\
& $(0.24)$ & $(0.32)$ & $(0.31)$ & $(0.14)$ & $(1.14)$ & $(0.35)$ & $(0.24)$ \\
Profit share & 0.117 & 0.268 & 0.205 & 0.073 & 0.620 & 0.027 & 0.236 \\
& $(0.29)$ & $(0.43)$ & $(0.37)$ & $(0.10)$ & $(0.87)$ & $(0.41)$ & $(0.34)$ \\
Overtime & 0.348 & 0.569 & 0.254 & 0.101 & 0.398 & 0.460 & 0.575 \\
& $(0.39)$ & $(0.47)$ & $(0.49)$ & $(0.08)$ & $(0.54)$ & $(0.41)$ & $(0.61)$ \\
Bonus & 0.356 & -0.950 & 0.370 & 0.088 & 0.734 & & 0.434 \\
& $(0.24)$ & $(0.83)$ & $(0.30)$ & $(0.10)$ & $(0.63)$ & & $(0.26)$ \\
Other income & 0.545 & 0.039 & 0.690 & -0.039 & 0.670 & 0.300 & 0.631 \\
& $(0.38)$ & $(0.14)$ & $(0.51)$ & $(0.06)$ & $(0.72)$ & $(0.31)$ & $(0.44)$ \\
year 2007 & $587.922^{*}$ & $658.947^{* *}$ & 335.924 & 201.840 & 430.421 & 414.143 & $1423.461^{* *}$ \\
& $(251.84)$ & $(244.65)$ & $(370.37)$ & $(137.13)$ & $(667.36)$ & $(304.53)$ & $(483.34)$ \\
Constant & $-6442.468^{* *}$ & -626.666 & $-7885.586^{* *}$ & -1498.061 & $-11782.532^{* * *}$ & $-5063.400^{* *}$ & 644.198 \\
& $(2372.45)$ & $(1366.65)$ & $(2455.26)$ & $(897.43)$ & $(2972.40)$ & $(1771.59)$ & $(6025.29)$ \\
\hline$R^{2}$ & 0.355 & 0.257 & 0.395 & 0.251 & 0.479 & 0.600 & 0.316 \\
$N$ & 360 & 96 & 264 & 160 & 212 & 180 & 180 \\
$F$-stat & 1.00 & 0.83 & 1.05 & 1.38 & 1.03 & 2.91 & 1.38 \\
$p$-value & 0.426 & 0.554 & 0.399 & 0.231 & 0.411 & 0.018 & 0.231 \\
\hline The & & &
\end{tabular}

The $F$-test pertains to testing whether all income coefficients, except for Total income, are jointly equal to zero. 
Table 6: Test results eq. (15)

\begin{tabular}{llrrrrrrrr}
\hline & & \multicolumn{3}{c}{ Monthly data } & & \multicolumn{3}{c}{ Annual data } \\
\cline { 3 - 4 } \cline { 7 - 9 } & & All & Bank & Insurer & & All & Bank & Insurer \\
\hline$J=1$ & $F$-stat & 27.22 & 30.49 & 1.52 & & 4.71 & 4.29 & 1.00 \\
& $p$-value & 0.000 & 0.000 & 0.174 & & 0.000 & 0.000 & 0.426 \\
& & & & & & & \\
$J=2$ & $F$-stat & 91.26 & 57.80 & 2.85 & & 4.46 & 4.31 & 8.82 \\
& $p$-value & 0.000 & 0.000 & 0.000 & & 0.000 & 0.000 & 0.000 \\
& & & & & & & \\
$J=3$ & $F$-stat & 3.29 & 3.29 & 95.75 & & 18.90 & 49.20 & 78.40 \\
& $p$-value & 0.000 & 0.000 & 0.000 & & 0.000 & 0.000 & 0.000 \\
\hline
\end{tabular}




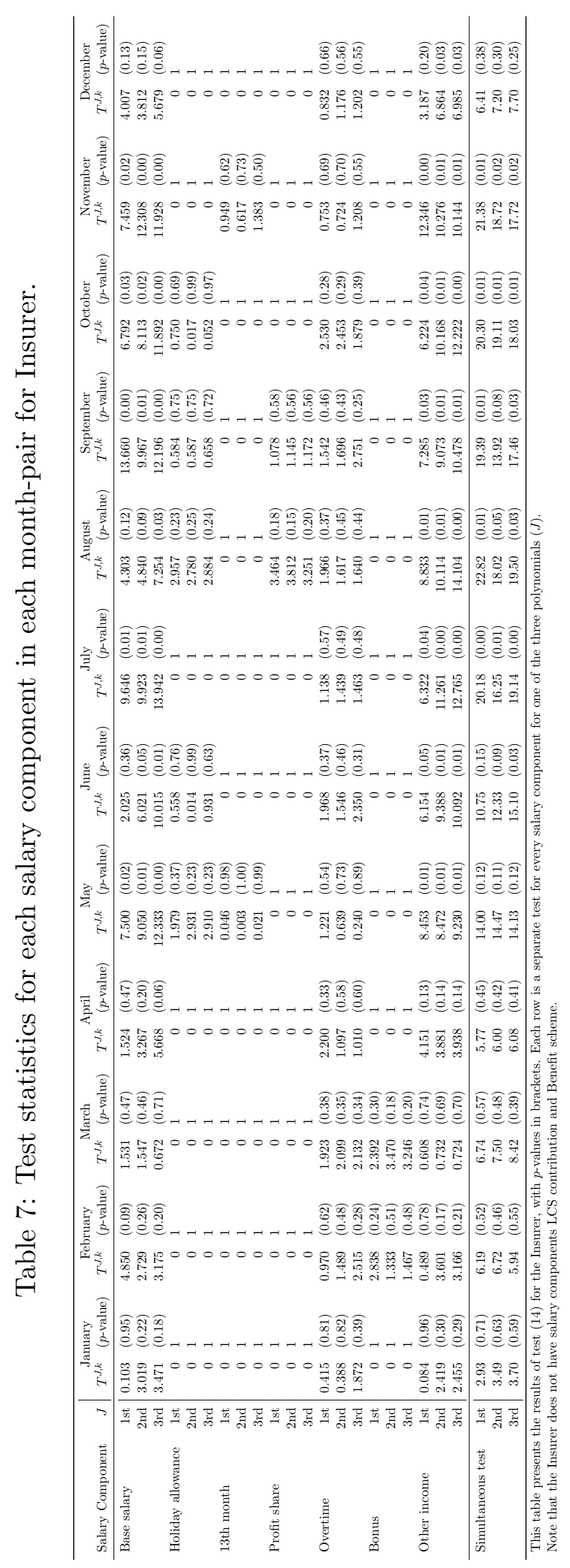




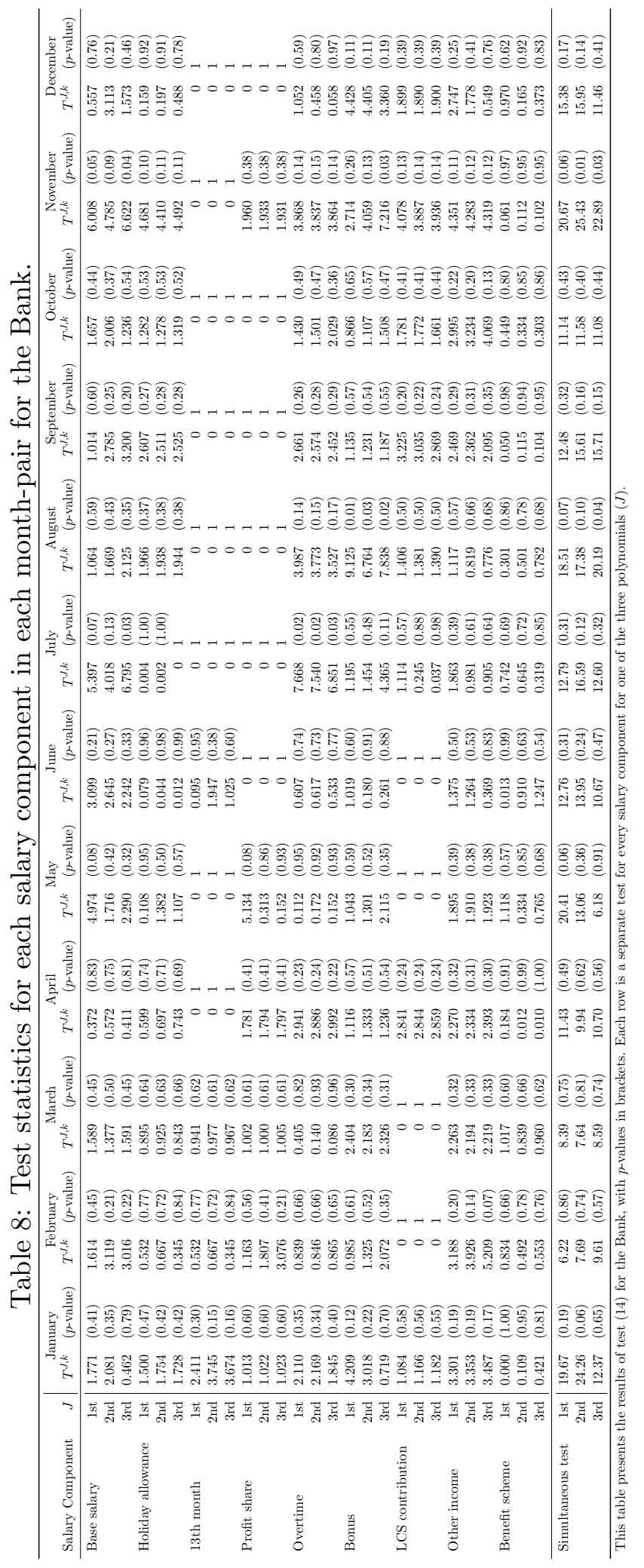




\section{Appendix: Institutional details}

The Life Course Savings Scheme was introduced in 2006 to promote life cycle planning and better balance work and private life. Workers are stimulated to save for those periods in their lifecycle in which their personal circumstances make it attractive to have more leisure time. The tax facilities related to the LCS include tax deferral, tax subsidies for parents who use the LCS for staying at home with young children, and tax exemptions for employers' contributions.

The LCS scheme allows workers to save up to a maximum of $12 \%$ of their salary per year, while the total balance should not exceed 210 percent of their annual wage. As mentioned, saving in the LCS means tax-deferral: the saved share of income is untaxed at the time of saving. LCS money can be used (and is then taxed) to finance parental leave, care leave and education, as well as early retirement. If it is used for parental leave, employees get additional tax reductions, which can amount to 632 euro a month. While the LCS was introduced to facilitate combining family life and working life over the life cycle, the ESS was introduced to stimulate savings in general. The amount of money that can be saved in the ESS is much smaller than in the LCS. After four years of savings on a blocked account, the maximum tax deduction gained by ESS participation is a mere 600 euro. Whereas LCS money must be spent on buying leisure time, money in the ESS can be spent at the discretion of the employee.

The Dutch LCS differs from the recent initiatives in Sweden and the US to privatize social security. First, saving in the LCS is encouraged, but not mandatory. Second, LCS participants do not necessarily have investment risk, as accounts typically offer a fixed interest rate. Third, taking out the LCS money is only permitted for buying leisure time. Fourth, the plan does not substitute existing social security arrangements in the Netherlands. Fifth, the main goal was to assist two-income earners to both work and have time to raise children, not for retirement planning.

Workers who up to 2006 did partake in the ESS and wanted to change had to actively op-out of the ESS and enroll in the LCS. Employees can switch every calendar year from one scheme to the other. Savings built-up in either scheme are retained when an employee switches.

\section{Implementation at the Bank and the Insurer}

Both the Bank and the Insurer offers accounts in the Life Course Savings scheme as well as the Employee Savings scheme as financial products to the general public. Therefore, both firms have are interested in encouraging LCS participation also among their employees. If an employer chooses to grant LCS contributions as a part of the wage package, law mandates that all of his employees should indiscriminately receive such a contribution, whether 
or not they participate in the LCS. Moreover, although labeled as LCS contribution, there are no restrictions for employees on how to spend it. Thus an employer's LCS contribution does not differ from other parts of the wage package, except for its label "LCS contribution".

Promotional activities for LCS participation differed somewhat between the Bank and the Insurer. The Bank offered a relatively high interest rate on LCS savings, and in addition awarded a bonus for employee savings for five years in a row (10\% over the summed interest of these five years). Employees who preferred to invest in stocks rather than to save were exempted from paying transaction costs on buying and selling stock. In October 2005, all employees of the Bank received a letter inviting them to participate in the LCS with the details of this promotional offer, a product flyer, and a form to express interest in participating. The only action required to enroll was to put a preprinted sticker on the form and send it back to a pre-printed postpaid envelop.

The Insurer made promotional efforts among the employees stage-wise during the year 2006. The motivation to opt for phased implementation was the fact that there were already several other changes for employees in January 2006, like the major reform in the Dutch health insurance system, a change in the fiscal treatment of lease cars, and a change in the pension act. These changes required the attention of employees as well as the firms' personnel departments. In January 2006, the Insurer sent a product flyer about the Life Course Savings scheme together with the salary slip. In the months April, May, and June of 2006 the Insurer organized in all its locations information campaigns for employees. There were no advantageous interest rates for employees of the Insurer. Once an employee has an LCS account, (s)he can easily change the amount of savings by accessing the firm's intranet-site. If an employee changes the amount of his inlay before the 10th of the month, this change will be in effect the next month. 